\title{
Labor and environment in global value chains: an evolutionary policy study with a three-sector and two-region agent-based macroeconomic model
}

\author{
Lena Gerdes $^{1} \mathbb{D} \cdot$ Bernhard Rengs $^{2} \mathbb{D} \cdot$ Manuel Scholz-Wäckerle $^{3} \mathbb{D}$
}

Accepted: 13 October 2021 /Published online: 14 January 2022

(c) The Author(s) 2022

\begin{abstract}
The world economy crucially depends on multi-layered value chains with high degrees of sector-related specialization. Its final products are of international character and serve the needs and wants of the global citizen. However, many production processes are causing severe damage to the environment and moreover create health hazard for workers and local populations. This research article focuses on the increasing global unequal economic- and ecological exchange, fundamentally embedded in international trade. Resource extraction and labor conditions in the Global South as well as the implications for climate change originating from industry emissions in the North are investigated with an agent-based model. The model serves as a testbed for simulation experiments with evolutionary political economic policies. An international institution is introduced sanctioning the polluting extractivist sector in the Global South as well as the emitting industrial capital good producers in the North with the aim of subsidizing innovation reducing environmental and social impacts. Both regions are modelled as macroeconomic complex adaptive systems where international trade is restricted to a three-sector value chain, originating from mining resources in the South that are traded to capital good producers in the North crafting machinery which is eventually
\end{abstract}

Lena Gerdes, Bernhard Rengs and Manuel Scholz-Wäckerle contributed equally to this work.

Manuel Scholz-Wäckerle

manuel.scholz-waeckerle@wu.ac.at

Lena Gerdes

lena.gerdes@wu.ac.at

Bernhard Rengs

bernhard.rengs@oeaw.ac.at

1 Institute for Economic Geography and GIScience, Department of Socioeconomics, Vienna University of Economics and Business, Vienna, Austria

2 Wittgenstein Centre for Demography and Global Human Capital (IIASA, OEAW, University of Vienna), Vienna Institute of Demography/Austria Academy of Sciences, Vienna, Austria

3 Department of Socioeconomics, Vienna University of Economics and Business, Vienna, Austria 
traded to consumer good firms, both in the North and South. The main outcome of the study is that sanctions alone are not effective in countering unequal exchange. They only make a difference in combination with subsidies for innovation activities, which are protecting labor and reducing local pollution in mines as well as reducing carbon-emissions in capital good production.

Keywords Evolutionary political economy · Agent-based modelling · Unequal exchange $\cdot$ Resource extraction · Global value chains $\cdot$ Labor and environmental protection $\cdot$ Climate change

JEL classification $\mathrm{B} 52 \cdot \mathrm{C} 63 \cdot \mathrm{F} 12 \cdot \mathrm{F} 18 \cdot \mathrm{F} 64 \cdot \mathrm{F} 66 \cdot \mathrm{F} 68 \cdot \mathrm{O} 13$

\section{Introduction}

The world economy is a highly interlinked, interdependent and fragmented production system. The evolutionary process of political economic globalization leads to complex value chains regarding natural resource extraction and capital good production in particular. Final goods are largely of international character, serving the needs and wants of global citizens. However, each step in such complex value chains potentially causes severe damage to the environment or violates labor and human rights (European Parliament 2021). Most of these negative effects are happening far away from the place where the final good is eventually consumed. The historical and geographical traces of multi-sectoral value chains become invisible once the final product finds its place in the shelves of local and international retailers. The impacts of production on labor and the environment often have to be carried by the producing countries, majorly the Global South, while profits are accumulated in the Global North. This causes economic, social and ecological tensions and inequalities within and between political economic regions, often studied under the term unequal exchange (Muradian and Martinez-Alier 2001; Ricci 2019; Dorninger et al. 2021).

To tackle social-ecological impacts emerging from global value chains, several global institutions are in place, which structure international trade, like the WTO or the universal declaration of human rights more generally. However, they are not very effective in preventing damage to the environment and local populations. Moreover, they strongly rely on voluntary commitment to due diligence from multinational organizations, since it is expected that companies would want to avoid damage to their reputation (European Parliament 2021). But, as numerous recent studies show, among others from the European Commission (Faracik 2017; Smit et al. 2020), the voluntary approach is not sufficient to reduce negative impacts along value chains. The European Parliament recently adopted a non-binding resolution, arguing the EU "should urgently adopt binding requirements for undertakings to identify, assess, prevent $[. .$.$] and remediate potential and/or actual adverse impacts on human rights,$ the environment and good governance in their value chain" (European Parliament 2021). 
Evolutionary economists were always interested in investigating international trade and its effects on structural and industrial change, inequalities, development and growth. Stimulating examples are given by Maggi (1993), Mainwaring (1993), Daly (1995), Amable (2000), Kingston (2000), Herrmann-Pillath (2006), Fagiolo et al. (2010), Gaffard and Saraceno (2012), Hanappi (2019) and Landesmann and Stöllinger (2019), following a variety of different perspectives and approaches. This research article aims to contribute to this stream of evolutionary political economic research by presenting an agent-based model of unequal exchange. The macroeconomic nature of the model we present is in similar spirit as given by Dosi et al. (2010), Ciarli et al. (2010), Cincotti et al. (2010), Delli Gatti et al. (2011), Seppecher (2012), Lengnick (2013), Ricetti et al. (2013), Chen et al. (2014), Dawid et al. (2014), Lorentz et al. (2016), Caiani et al. (2016), and Safarzyńska and van den Bergh (2016). In particular, it is inspired by Rengs and Scholz-Wäckerle (2014, 2017, 2019) and Rengs et al. (2020).

Agent-based macroeconomic models with multiple regions and trade relations are seldom. Existing agent-based economic models with trade are presented e.g. via the Euroace@Unibi model, which forms the basis for several studies, with a focus on the European labor market and the stability of financial markets (Dawid and Harting 2012; Dawid et al. 2014, 2018; Petrovic et al. 2017, 2020). Financial markets itself form the basis for another family of models (see Chiarella and Di Guilmi 2011; Grauwe and Gerba 2017; Caiani et al. 2018) as well as the development of trade markets, and trade agreements, including tests of different strategies and the impact of free trade. For example, Lee et al. (2010) are using a game-theoretical approach, Caiani et al. (2019) are investigating the interdependence of European trade and wage regimes and Dosi et al. $(2019,2020)$ are studying growth patterns of interdependent economies in a multi-country agent-based model.

However, none of these models have an environmental component with feedback on the fragmented multi-regional production structure (e.g. health of workers or damaging the means of production), where global value chains clearly have a weak spot. Still, the presented agent-based model does not aim to mimic agent-based integrated assessment models, as recently published by Lamperti et al. (2018). There are some economic models with multiple regions specialized on climate policies, like the Lagom model family (Wolf et al. 2013). Nevertheless, all of these models still lack a conception of value chains. Our agent-based modelling approach integrates two very crucial aspects of unequal exchange, involving a decline in labor and environmental conditions in the Global South, i.e. (1) worsening labor conditions caused by local pollution and (2) increasing risk for natural disasters caused by endogenous global climate change.

Following this urgency to institutionalize mechanisms to reduce harm caused along value chains, we address the increasing global drift in unequal economic- and ecological exchange, fundamentally embedded in international trade in this research article. We pay attention to the role of manufacturing firms (capital good producers) from the secondary sector of the Global North as trading hubs in the fragmented world economy. They usually depend on purchasing resources (such as raw materials) from the primary sector of the Global South in order to manufacture machinery for the final goods sector (consumption good firms as well as wholesalers and retailers) of both, the Global South 
and North. The latter firms use this machinery to assemble, transport, distribute and eventually sell final products to final consumers in their domestic economy. This threesector global value chain schema represents a large part of the fragmented production of the world economy, including its social and ecological consequences. We investigate historically and spatially evolved dependencies of the world economy with an emphasis on unequal exchange (Ricci 2019), in a three-sector, two-region agent-based model of an artificial world economy. Evolutionary economic policies protecting labor and the environment are tested, in order to reduce unequal exchange. For this very purpose we refer to the concept of civilized markets introduced by Kapeller et al. (2016) who are highlighting the significant role of international institutions in making global value chains more just and less carbon intensive.

The article is organized as follows. In Section 2, we elaborate on the motivation of this framework with an emphasis on the fragmentation of the international production system, unequal exchange and climate change. Furthermore, we discuss the role of global institutions in operating policies aiming for more just and less carbon intensive global value chains. Section 3 will introduce the two-region, three-sector agent-based model and Section 4 discusses the results of evolutionary economic policy experiments. Section 5 concludes.

\section{The evolutionary political economy of economic fragmentation and unequal exchange}

According to Ricci (2019) "Unequal exchange arises when spatial production of value is disjointed from its geographical distribution” (p. 225) and can increasingly be observed in the current times of economic globalization (see also Emmanuel 1972, Amin 1974). The result is uneven development in the world system (Harvey 2006), originating from the transfer of wealth from poorer countries to richer ones (Foster and Holleman 2014), which is deeply rooted in historical developments of global value chains and complex power relations (see Suwandi 2019; Fischer et al. 2021). Next to a political economic perspective, there is an equally important ecological one, which is explored by an extending body of literature (see Muradian and Martinez-Alier 2001; Hornborg 2006; Jorgenson 2006; Jorgenson and Rice 2007; Lawrence 2009; Ricci 2019; Dorninger et al. 2021). Many countries of the Global South are facing ecological disadvantages, often, but not exclusively, imposed on them by countries of the Global North. In comparison, the ecological intensity of exports from countries of the Global South is often much higher than from countries of the Global North (Moran et al. 2013), mainly caused by the extraction of large amounts of resources which are needed for the production of machinery and final goods. The following section addresses these impacts of resource extraction on the economy, the environment and local population.

\subsection{Resource extraction, unequal exchange and climate change}

In the past decades, the demand for raw materials, in particular nonrenewable resources, increased strongly especially by industrialized, but also by emerging 
countries (Svampa 2013; Krausmann et al. 2017). The resources are an essential part of the economic success, prosperity and industrial development, specifically in the Global North. However, the process of extraction creates significant social and ecological challenges at the place of extraction (Acosta 2013). ${ }^{1}$ The concept of extractivism coins this linkage, referring to "mining, oil, monocultural agriculture, as well as other sectors that provide materials, usually for export" (Lang and Mokrani 2013). Generally, extractivism describes a division of labor on a global level. The raw materials are extracted or produced by some countries, often from the Global South, and then exported to other countries, often from the Global North, where they are used to produce capital goods such as machinery and equipment (Lang and Mokrani 2013). Many resource-rich countries of the Global South, especially in South America, experienced a so-called re-primarization, which describes a stronger focus on the exploitation and trade of natural resources. In South America, for example, the export of primary products constitutes more than half, and up to over $90 \%$ of the total exports (Gudynas 2009). The reasons for this development are manifold. Many resources are distributed very heterogeneously across the planet and the extraction depends on existing deposits (Schaffartzik et al. 2016). Moreover, incentives are given by rising industrial demand, rising commodity prices, and large-scale foreign direct investment (FDI) (Veltmeyer and Petras 2014). Additionally, there is a strong tendency of countries from the Global North to actively shift extractive and high polluting industries to countries of the Global South, due to lower production standards, lower labor costs and the attempt to outsource the high ecological and social costs linked to extractive industries. This process if often referred to as "burden-shifting” (Krausmann et al. 2017) or “externalization” (Lessenich 2019).

While the extraction and export of natural resources is an important source of income (Giarracca and Teubal 2014), it leads to an increasing dependency on the global market (Svampa 2013) and the profits are not equally distributed. Mines are often owned or operated by foreign corporations and registered in tax havens (Acosta 2013). Consequently, large parts of the revenue leave the country. Even in countries with governments officially declaring to limit the power and the profit of multinational corporations, like in Bolivia, the greatest beneficiaries are still large multinational corporations, and the government only takes a small share of the total profits (Veltmeyer and Petras 2014). Moreover, the raw materials are almost exclusively exported and processed abroad, where other countries profit from higher values of capital and final goods (Gudynas 2009). This development leads to strong global inequalities in terms of trade and costs caused by resource intensive industries. Looking at the European trade with Latin- and South America, this inequality becomes clearly visible. Europe mainly exports machinery and manufactured goods, hence goods with a high profit and high value added (Gudynas 2009), whereas it imports mainly primary products like food and animals, as well as crude materials and fuels (García-Herrero and Chiacchio 2017).

Next to economic unequal exchange, most of the environmental and social cost have to be carried by the countries exporting natural resources, especially the local

\footnotetext{
${ }^{1}$ See Kapp $(1950,1970)$ for an original evolutionary economic concept of social costs incurred by ecological crisis.
} 
communities, while they only receive a very small part of the revenue (Acosta 2013). Social and ecological consequences of the extraction of resources are numerous. The social structures are challenged and democratic mechanisms are undermined, since local communities often have no possibility to take part in decisions. The release of a large variety of chemicals, sewage waters, and solid wastes pollute the direct surrounding of the places of extraction, as well as places further away, which are connected through natural water systems (Dudka and Adriano 1997). The pollution can cause chronic diseases and other health issues, and can have negative impacts on the quality of the soil (Giarracca and Teubal 2014). Through the massive extraction of resources, "serious and irreversible destruction of the ecosystem" (Giarracca and Teubal 2014) is caused. Moreover, the effects are not limited to local destruction of the environment, but also contribute to global challenges like climate change. However, as Muradian and Martinez-Alier (2001) describe: "[under] neoclassical thought it will be perfectly logical to displace environmental load to poorer countries even if the rich countries have to financially compensate the environmental degradation of cheap land and diseases and deaths of poor people" (p. 293), especially because the costs depend on the large income inequalities.

\subsection{A global evolutionary political economy perspective}

Extractivism and unequal exchange in economic, social and ecological terms are crucial contemporary challenges, which are fundamentally rooted in the historical development of the world economic system (e.g. see Wallerstein 1983; Harvey 2006; Hornborg et al. 2007). In order to steer common practices away from unsustainable and unjust trajectories, new international mechanisms are needed. Here, the role of institutions can be highlighted. Currently, there are several global institutions in place, which guide international trade, like the WTO or the universal declaration of human rights. These are, however, not enough to effectively meet the ecological and social problems caused by global value chains (Lang and Mokrani 2013; Svampa 2013; Kapeller et al. 2016), equally ineffective as relying on voluntary commitment to due diligence by corporations (European Parliament 2021). In order to protect labor and the environment, institutions observing and evaluating all instances of international trade are necessary. However, to be effective, these institutions need to have the ability to control and implement international standards, e.g. via taxes, penalty-tariffs and financial incentives to invest into labor and environment protection.

A proposal in this direction was made by Kapeller et al. (2016), introducing the concept of civilized markets: a "civilized market tries to ensure that free entrepreneurship and open markets are eventually compatible with those basic and universal values that also serve as moral cornerstones of the European project" (p. 320). The authors propose an institution, which has the mandate to "set and enforce minimum standards for goods sold on the European market" (p. 320), since the competitive market system currently in place undermines the environmental, social and moral foundations of our society and fosters unethical behavior such as child labor, corruption, and the manipulation of earnings (Shleifer 2004). In order to counter these developments, Kapeller et al. (2016) suggest - in Polanyian tradition - "to modify and improve the social embedding of market activities in international trade by introducing appropriate institutions and politics in order to achieve a better alignment between social standards and market competition" (p. 323). 
Taking these arguments into account, this paper follows an evolutionary political economy perspective (Hanappi and Scholz-Wäckerle 2017), addressing the systemic complexity of a policy framework for multi-regional redistribution. We take particular care for the feedback loops between micro and macro in each region and highlight the importance of power, knowledge and learning in evolutionary policy making (see Kapeller and Scholz-Wäckerle 2016). In particular, an institutional policy is tested with emphasis on labor and environment protection. Gains from this policy are not merely redistributed across households, but used to invest in labor and environmental protection. Emphasis is given to directly steering firms to new social-ecological paths, while only assuming learning-by-imitation from other firms in their networks. Details of the policy are explained in section 4 , after a thorough description of the model in the following.

\section{The structure of the three-sector two-region agent-based model}

In the model, heterogeneous agents interact in a self-organizing and endogenously developing economy. The economy contains two distinct regions - an abstract Global South and Global North. There are three interlinked sectors, the consumption good-, capital good-, and resource production sector. Each region contains an independent consumption good sector, with domestic demand for final goods. They produce a fictitious consumption good basket (see Rengs and Scholz-Wäckerle 2019), and sell it to the households in the respective region. The production within each consumption good firm is based on the same production function, which uses labor and physical capital (machine capacities) in a constant relation as inputs. However, the prices, wages, number of workers and physical capital of the firms develop independently throughout the simulation. The other sectors are only present in one region. The capital good sector is only found in the Global North, meaning capital goods (i.e. machines) are exclusively produced there, but are traded to the foreign as well as the domestic market as an intermediary. For the production of machines, capital firms need labor, machines themselves and resources. Prices and wages are, like in the consumption good sector, developing independently in each capital firm. The resource production sector, on the other hand, is only located in the Global South. Mines extract resources and export them to the capital firms in the North. For the extraction of resources, the mines need labor and machines.

The households form the labor force in their respective region, there is no movement of labor. The governments in both regions collect taxes from all firms and pay unemployment benefits. Firms and banks form a simplified credit market, where firms can borrow from banks to finance all payments and investments if they are illiquid.

In addition to economic interactions, the model also includes ecological as well as social factors. Capital firms of the North produce carbon emissions, which are functioning as a proxy for global emissions. The emissions are causing climate change, leading to natural disasters damaging firms (machines) of all sectors eventually. Mines of the South produce local pollution, affecting the health of mineworkers and thereby decreasing their labor productivity. The basic flow structure of the model is presented in Fig. 1. A more detailed description of economic agents and structures is given in following sub-sections as well as in the appendices. 


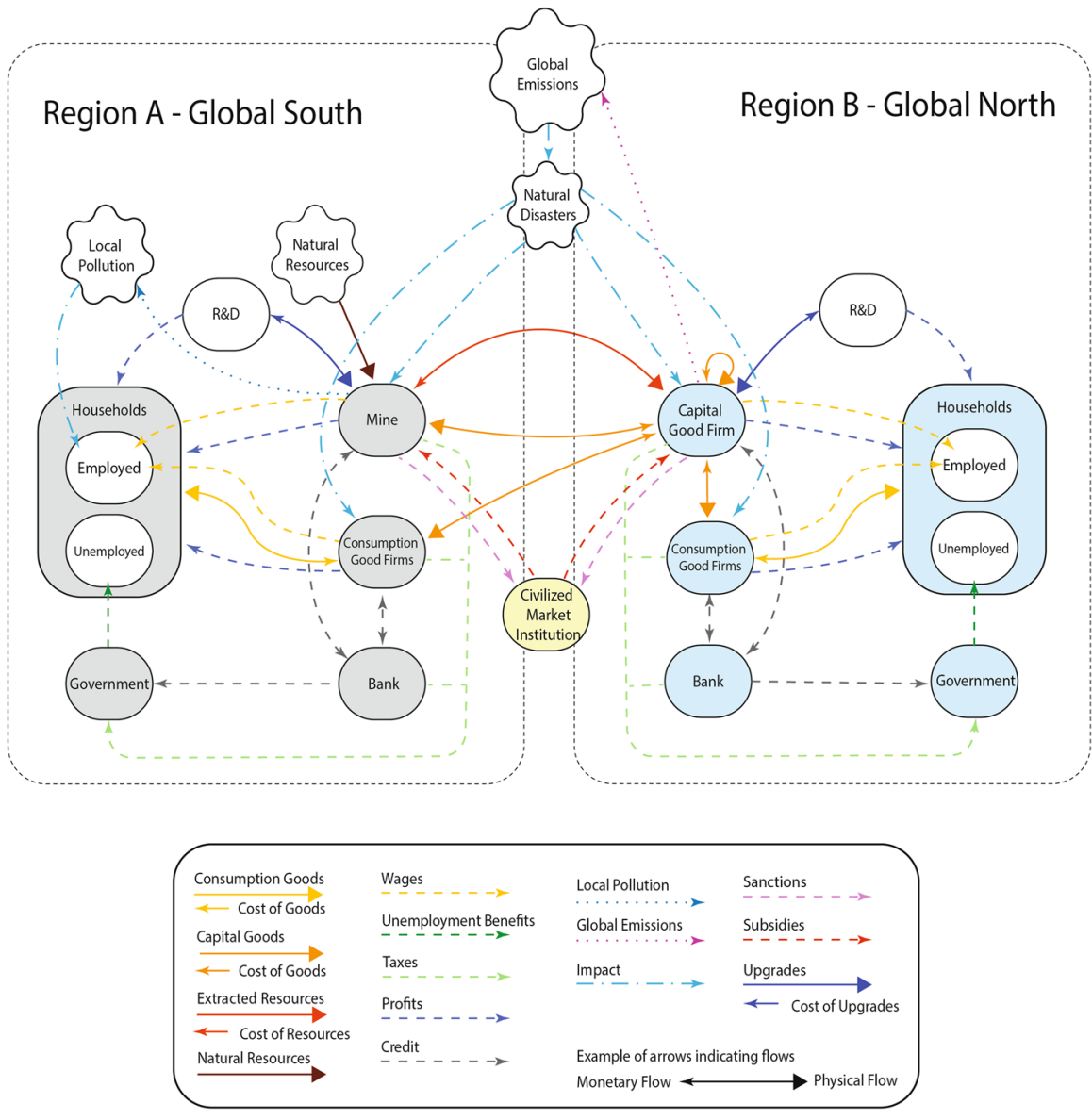

Fig. 1 Basic flow-chart structure of the model

\subsection{Households}

Households are boundedly rational agents based on satisficing rather than optimizing behavior, they form the workforce in both regions and buy consumption goods. Similar to Lengnick (2013) and Rengs and Scholz-Wäckerle (2019), each household keeps a shortlist of preferred consumption good firms that they are willing to buy from at a given point in time. At the start of the simulation, the lists contain $n$ randomly selected consumption good firms, where $n=\alpha_{1}$. Throughout the simulation, the households update this list, based on their experiences with the firms as well as the prices. Each month, with a $25 \%$ chance, each household adapts its list in a twostep process. First, they pick one of the vendors on their list and compare its prices to a randomly chosen consumption good firm. If the price of the randomly chosen one is lower than that from the firm on the list, the household replaces the old firm with the new one with a $25 \%$ chance. In the second step, households may replace 
firms that did not satisfy their needs, due to limited inventories. With a probability of $25 \%$, the household replaces the firm with a randomly chosen new one.

Each round, households plan their consumption based on their available budget ( $m_{h, t}$, where $h$ denotes the household and $t$ the time), which consists of the monthly income $\left(i n_{h, t}\right)$ as well as a share of the household's savings $\left(s_{h, t}\right)$ (see Appendix 4 for equations). The desired consumption $\left(c_{h, t}^{w}\right)$ in units of goods is based on the budget, as well as on the mean price of the consumption good firms on the shortlist of preferred vendors $\left(\bar{p}_{i, t}^{\text {pref }}\right)$ :

$$
c_{h, t}^{w}=\frac{m_{h, t}}{\bar{p}_{i, t}^{p r e f}}
$$

The purchase of goods is organized in two rounds, to ensure that it is possible to fulfil the minimum consumption need of goods for all households, in case of limited stocks of the firms. In the first round, they only buy a part of the desired amount, and in the second round the remainder, as far as possible. If during any step of the purchase-process the consumption good firm cannot provide the desired goods to the household, the household makes a note regarding the failure of the firm to satisfy its demand and moves to another firm on the list in order to ask for the missing amount of goods. In both rounds, the households repeat the process with each firm on their list, or until they are satisfied.

\subsection{Firms}

There are three different types of firms: consumption good-, capital good-, and resource production firms (mines). All firms follow similar behavioral rules, however, there are significant sector-related specificities, discussed in detail in the following.

\subsubsection{Consumption good firms}

Consumption good firms (called "consumption firms" in the following) form the largest part of the economy and produce the goods which the households are buying. At the start of the simulation, each consumption firm in the same region is identical: they have the same number of workers, pay the same wage and sell their goods for the same price. At that time, the only difference between the consumption firms in the Global North and the Global South is the wage. In the Global South, wages are $25 \%$ lower than in the North, loosely following existing wage differences (OECD 2020). All consumption firms are assigned a physical capital stock (machine capacities $\left(x_{i, t}^{c}\right)$, where $i$ denotes the firm and $t$ the time), matching the initial labor $\left(x_{i, t}^{l}\right.$, i.e. the number of workers). The consumption firms adapt production, pricing and wages following a short-run strategy, based on changes of the individual demand for their goods. Nevertheless, they only adapt their plans slowly. They plan the 
production $\left(q_{i, t}^{p^{\prime}}\right)$ based on the production from the last period $\left(q_{i, t-1}^{p}\right)$ and the amount of unsold goods left $\left(q_{i, t-1}^{p s}\right)$, which are reduced each month by a sector specific depreciation rate $\left(\delta_{1}^{\text {cons }}\right)$, and on excess demand $\left(q_{i, t}^{e x}\right)$ which could not be satisfied, to meet changes in demand and adapt the production accordingly.

This leads to the following production plan:

$$
q_{i, t}^{p^{\prime}}=q_{i, t-1}^{p}+q_{i, t}^{e x}-q_{i, t-1}^{p s}
$$

Firms define excess demand each round anew. As applied by Rengs and Scholz-Wäckerle (2019), following ideas from Godley and Lavoie (2006), consumption firms want the inventory after sales $\left(q_{i, t-1}^{p s}\right)$, i.e. the unsold goods, to stay at an optimal level $\left(q_{i, t}^{o p t}\right)$. The optimal level is proportional to the previously produced goods $\left(q_{i, t-1}^{p}\right)$ by the factor $\alpha_{2}$ :

$$
q_{i, t}^{o p t}=\frac{q_{i, t-1}^{p} \alpha_{2}}{1+\alpha_{2}}
$$

If the current level of unsold goods is too low, meaning sales were higher than expected, firms plan to increase production. Vice versa, they plan to decrease production if the level is too high. To adjust the production plan, they define $q_{i, t}^{e x}$ proportional to the optimal reserve by the parameter $\alpha_{4}$. Moreover, they adapt the price of the good $\left(p_{i, t}\right)$ by a fraction $\left(\alpha_{3}\right)$ of region $(R)$ specific maximum amount $\left(p_{R}^{m c h}\right)$ (for details see Appendix 4, Eqs. 33-49).

Production Firms produce using a transformative production function in which the output $\left(q_{i, t}\right)$ depends on the machine capacities $\left(x_{i, t}^{c}\right)$ and labor $\left(x_{i, t}^{l}\right)$ available, as well as a capital intensity coefficient ( $\left.\alpha_{5}^{\text {cons }}\right)$ and a constant production-technology coefficient $\left(\alpha_{6}^{\text {cons }}\right)$ :

$$
q_{i, t}=\alpha_{6}^{\text {cons }} \min \left(x_{i, t}^{c}, \alpha_{5}^{c o n s} x_{i, t}^{l}\right)
$$

In advance, the firms can change the production inputs $\left(x_{i, t}^{c}, x_{i, t}^{l}\right)$ to meet the planned production $\left(q_{i, t}^{p \prime}\right)$. Consumption firms in the South may adapt labor every month, in the North, due to better labor protection, only every two months. Machine capacities are adapted every month in both regions.

If the available labor is not sufficient for the intended production plan, the consumption firm searches for possible workers (unemployed households) in its region and, if available, hires as many as needed. However, a firm will not increase its labor to more than $a_{7}$ times its previous labor force in one month.

If its production plan would require hiring more than available or the previously mentioned limit allows, then the highest possible amount is hired and the planned production is corrected downwards to the new capacities. If a firm has too much 
labor available, it fires the surplus. Each round, however, only a limited number of workers can be fired (see Appendix 4, Eqs. 50-56).

After adjusting labor capacity, machine capacity is addressed. Monthly depreciation reduces machine capacity as well as the value of all firms' capital. If, after depreciation, a firm does not have enough machine capacity available to produce the planned amount, it plans to acquire more, a reduction however, is not possible.

Each consumption firm has a shortlist of $\alpha_{10}$ capital firms, from which it can buy machine capacities. This list is updated every three months, following the same updating rules as the households' shortlist of consumption good firms (see sub-section 3.1).

In order to buy machines, a consumption firm calculates the required funds and seeks to acquire a loan if it does not have the necessary means available. The bank in the respective region of the consumption firm grants the loan if the expected profit rate $\left(r_{i, t}^{e}\right)$ of the respective firm is larger than the interest rate of the bank (ir), factoring in a credit-lenience $\left(\nu_{1}\right)$ parameter, which is the same for every bank (see Appendix 4, Eqs. 57-60).

If the loan is granted, the firm continues with the purchase of the additional machines. If the loan is not granted, the firm reduces the number of machines it wants to buy to the maximum amount possible given its remaining funds. Then, the consumption firm requests a fraction $\left(x^{c} / \alpha_{10}\right)$ of the amount determined in the previous step from each capital firm on its list, which in sum matches the total number of aspired machines. If the capital firms have the requested machines in stock, the purchase is completed. If a capital firm does not have sufficient machines in stock, the maximum amount available is purchased, the costs are adjusted accordingly and the capital firm is marked as unsatisfying in the consumer firm's short list. If it was not possible to buy all requested machinery, the buying process is repeated with the missing amount, only considering capital firms from the list which still have machines in stock, until at least $95 \%$ of the needed machines are purchased, or no capital firm on the list can provide any further machines.

After the number of machines as well as labor was adapted, if necessary, the consumption firms produce consumption goods $\left(q_{i, t}^{p}\right)$ according to their capabilities (see production function, Eq. (4) above) and add the produced amount to their inventory $\left(q_{i, t}^{p s}\right)$ :

$$
q_{i, t}^{p s}=q_{i, t-1}^{p s}+q_{i, t}^{p}
$$

If a consumption firm did not produce anything for twelve consecutive months, it is considered bankrupt and is dissolved, thus releasing any potentially remaining workers.

\subsubsection{Capital firms}

Capital firms are only located in the Global North and produce machines, which are sold to all other firms in both regions (consumption good firms, other capital firms 
and mines). Wages paid by this firm type have the same starting value as consumption firms in the Global North. The production procedures are very similar to the ones of the consumption good sector. Setting the production plans and prices, as well as machine purchase and labor adaptation, follow the same rules, albeit using sector specific variables (see Appendix 4, Eqs. 61-88). Labor adaptation is carried out every second month. In addition to labor and machines, capital firms need resources as an input, which are consumed during the production. These are bought from mines in the Global South, in a process very similar to the purchase of machines (see Appendix 4, Eq. 89). The capital firms thus apply the following production function $\left(q c_{i, t}^{p}\right)$, adding the produced goods to their inventory $\left(q c_{i, t}^{p s}\right)$, while reducing the stock of resources $\left(x_{i, t}^{r}\right)$ :

$$
\begin{gathered}
q c_{i, t}^{p}=\alpha_{6}^{c a p} \min \left(x_{i, t}^{c}, \alpha_{5}^{c a p} x_{i, t}^{l}, \alpha_{12} x_{i, t}^{r}\right) \\
q c_{i, t}^{p s}=q c_{i, t-1}^{p s}+q c_{i, t}^{p}
\end{gathered}
$$

\subsection{Mines}

In the resource production sector, mines extract resources in the Global South and export them to the capital firms in the Global North. They follow the same logic as the consumption firms regarding the production planning process as well as in machine purchases (see Appendix 4 for equations), but pay much lower wages. Labor, however, is a special case. Mines cause local pollution, which has a negative effect on the workers. Depending of the level of the pollution in a specific mine, the productivity of the workers employed there deteriorates each period that the worker is employed there. Local pollution is described in more detail in sub-section 3.5. Thus, labor input is defined by the productivity of mines' workers $\left(x_{i, t}^{l-p r o d}\right)$, which is the sum of the individual productivity level of each worker of the mine $\left(\operatorname{prod}_{h, i, t}\right.$ with $h$ indicating the worker, $i$ the mine it is employed at and $t$ the respective point in time):

$$
x_{i, t}^{l \_p r o d}=\sum \operatorname{prod}_{h, i, t}
$$

For a detailed description of the hiring process, which takes the productivity into account, see Appendix 4, Eqs. 107-113. After adapting machine capacities and labor, mines produce, which means they extract the resources and add them to their inventory $\left(q m_{i, t}^{p s}\right)$.

$$
\begin{gathered}
q m_{i, t}^{p}=\alpha_{6}^{\text {mine }} \min \left(x_{i, t}^{c}, \alpha_{5}^{\text {mine }} x_{i, t}^{l \_p r o d}\right) \\
q m_{i, t}^{p s}=q m_{i, t-1}^{p s}+q m_{i, t}^{p}
\end{gathered}
$$




\subsection{Wages, transfers, loans \& taxes}

At the end of each month, after all households consumed and all firms produced goods, wages are paid by all firms (consumption firms, capital firms and mines) to their workers. Within each region's sector, wages start at the same level at the start of the simulation. They are adjusted once a year by each firm, though not by all firms in the same month, but rather distributed over the year to avoid the introduction of an artificial seasonal effect. Wages are downward rigid, but if a firm has positive profits, it increases wages, by a factor that depends on the relative increase of the firm's good price over the last 12 months and a sector-specific maximum adaptation rate (see Appendix 4). Wages are firm-specific, but all workers of the same firm receive the same wage, except in mines. Mines make the wage dependent on the productivity of the individual workers, who receive a share of the base-level equivalent to their productivity level (see Appendix 4, Eq. 118). Unemployed households receive unemployment benefits from the government of their region. The transfers amount to $80 \%$ of the mean wage in the region. After paying wages, all firms have to pay back part of their loans, the amount depends on the repayment rate of their bank ( $r r)$. At the end of the year, all firms calculate their profit and pay corporate taxes to their government, based on the tax rate $\left(t r_{g}\right)$.

Half of the profits of all firms are distributed to the households of the region the firm is situated in, as a proxy for households holding shares of the firms. Households receive a share of the distributed profits relative to their own wealth (savings), which is added to their savings. The R\&D-funds' (introduced in sub-section 3.7.) gains are also distributed in the same manner among households of the respective region.

\subsection{Local pollution at mines}

During the production process, mines cause local pollution $\left(\operatorname{pol}_{i, t}\right)$, which affects the health of the local workers, depicted as an effect on their productivity. At the start of each simulation, each agent's productivity is initialized as $\operatorname{prod}_{h, t}=1$, which decreases if an agent is employed at a mine. The scope of the pollution depends on the production volume $\left(q m_{i, t}^{p}\right)$ and a mine specific pollution rate $\left(\gamma_{i, t}\right)$ :

$$
\operatorname{pol}_{i, t}=q m_{i, t}^{p} \gamma_{i, t}
$$

The negative effect on the productivity of the workers $\left(\operatorname{prod}_{h, i, t}\right)$ depends on the mine specific pollution rate as well as a health-impact factor $\left(\alpha_{13}\right)$, but the productivity can never fall below $\frac{1}{3}$ :

$$
\operatorname{prod}_{h, i, t}=\max \left(\frac{1}{3}, \operatorname{prod}_{h, i, t-1}-\gamma_{i, t} \alpha_{13}\right)
$$

Agents in the Global South are replaced after 30 years by a new agent with equal properties (such as employer and savings) but with unreduced productivity. This assumption, serving as a crude proxy for retirement, allows exploring experiments where the population's productivity might partially or fully recover. 


\subsection{Global emissions}

Global emissions are caused only by the capital firms in the North as a byproduct of the production process. The amount emitted per capital firm $\left(e_{i, t}\right)$ depends on the amount of goods produced $\left(q c_{i, t}^{p}\right)$, the firm's emission rate $\left(\beta_{i, t}\right)$ and an emission factor $\left(\alpha_{14}\right)$ :

$$
e_{i, t}=q c_{i, t}^{p} \beta_{i, t} \alpha_{14}
$$

The total global emission stock $\left(e_{t}^{\text {global }}\right)$ is the sum of all previous global emissions and is increased by the monthly global emissions $\left(\sum e_{i, t}\right)$. We assume that the stock decreases monthly by a fixed amount, which is a fraction $\left(\alpha_{24}\right)$ of the emission base level at the start of the simulation $\left(e_{t=0}^{g l o b a l}\right)$. This is a crude proxy for natural carbon binding capabilities of the planet, which we assume to be constant. This also allows us to explore rather utopian experiments with outcomes where the total global emission stock may even start to gradually reduce in the medium run. The reduction however is set to a small level in order not to be overestimated.

$$
e_{t}^{\text {global }}=\left(e_{t-1}^{\text {global }}-\left(e_{t=0}^{\text {global }} \alpha_{24}\right)\right)+\sum e_{i, t}
$$

Increasing levels of global emissions increase the frequency of natural disasters, which may damage machines each month. The damage is randomly distributed between all firms in both regions, caused by small individual disasters ("hits") affecting firms, based on the following procedure:

1. As a crude proxy of the damage caused by each hit $\left(d_{t}\right)$ we calculate the floating average of total machine capacity in the ${ }_{t}$ whole system during the past 12 months multiplied by a damage-impact ${ }_{t}=\left(\frac{\text { altor }}{12} \sum_{t^{\prime}=(t-12)}^{t}{ }^{\left(a_{15}\right)} \dot{x}_{t^{\prime}}^{c}\right) \alpha_{15}$

2. The number of hits per month $\left(h_{t}\right)$ increases non-linearly with an increasing global emission stock and thus depends on the current stock of global emissions $\left(e_{t}^{\text {global }}\right)$ in relation to the base level $\left(e_{t=0}^{\text {global }}\right)$ as well as a scenario-specific acceleration rate $\left(\alpha_{16}\right)$. In the policy experiments (see section 4 ), three different acceleration rates are tested, to account for the huge $h_{t}=\left(\frac{\text { necertain }}{e_{t=0}^{\text {global }}}\right)$ ies in climate change acceleration

3. These individual disasters are randomly hit firms (consumption firms, capital firms and mines). Firms may be hit more than once per month, causing damages to accumulate $\left(d_{t}\right)$. The hit firms lose machine capacity equivalent to the damage, and their capital value $\left(\omega_{i, t}^{c}\right)$ decreases accordingly:

$$
\begin{gathered}
x_{i, t}^{c}=x_{i, t-1}^{c}-d_{t} \\
\omega_{i, t}^{c}=\omega_{i, t}^{c}\left(1-\left(\frac{d_{t}}{x_{i, t-1}^{c}}\right)\right)
\end{gathered}
$$


Firms in the South are indirectly affected more, since they have to replace the lost machine-capacities at the same price as firms in the North. However, price levels are much lower in the South, which leads to higher relative costs. This reflects tendencies that countries of the Global South tend to be affected stronger by climate change induced natural disasters, taking into account economic, social and human damage (Dinar et al. 2006; Eckstein et al. 2019), even without assuming that the South experiences more disasters.

\subsection{Innovation process}

To address emissions and local pollution, mines and capital firms can invest in innovation. Mines may purchase social-ecological and technical means reducing the local mine specific pollution rate $\left(\gamma_{i, t}\right)$. Capital firms may purchase socio-technical upgrades reducing the firm specific emission rate $\left(\beta_{i, t}\right)$. In the following, the innovation process of capital firms is elaborated, and the difference to the situation of mines is discussed towards the end.

At the start of the simulation, each capital firm is initialized with a planned innovation strategy $\left(i_{i, t}^{p}\right)$, which is randomly drawn from list of options. Each strategy on that list $\left(l_{1}=\right.$ $\{0 ; 0.2 ; 0.4 ; 0.6 ; 0.8 ; 1\})$ represents a differently ambitious plan to upgrade a fraction of the machines, where 0 represents no upgrade and 1 a complete upgrade. We assume that the firms have no intrinsic motivation to reduce emissions, which represents at least a worstcase scenario of the economy. Thus, we assume that capital firms observe the competition to assess the consequences of different innovation strategies, by maintaining an initially randomly filled short list of $n\left(n=\alpha_{17}\right)$ other capital firms. Firms evaluate the consequences of competitor's strategies based on the profit rate of those firms. Each year, before investing into innovation, the firm with the highest profit rate on that list is selected. In a second step, the realized strategy of this firm is compared with the own strategy realized last year. If the strategy of the competitor was to upgrade a higher share of the machines than the firm itself did, then the firm will try to upgrade a higher share than the year before. Strategies are only shifted by one share level, following the innovation strategy list (e.g., if the own strategy was 0.4 , and the strategy from the best firm was 0.8 , the own strategy would be increased by one step to 0.6). Respectively, the own strategy is reduced, if the strategy of the best firm was to upgrade a smaller share than the own. In case the firm itself had the highest profit rate on the list, it randomly adapts the strategy with a one-in-three chance.

After deciding which innovation strategy the firm would like to choose for the next year, it evaluates whether it has the required funds for the intended upgrades. The basic cost of the upgrade $\left(c u_{t}^{\text {base }}\right)$ depend on the current mean machine capacity price $\left(\overline{p c}_{t}\right)$ and the cost upgrade parameter $\alpha_{18}^{c a p}$ :

$$
c u_{t}^{\text {base }}=\overline{p c}_{t} \alpha_{18}^{c a p}
$$

The firm first evaluates the total cost $\left(c u_{i, t}^{e v a l}\right)$ for the firm's planned level of upgrade, which are based on $c u_{t}^{\text {base }}$, multiplied by the number of machines owned, times the share of the machines to be upgraded, i.e., the planned innovation strategy $\left(i_{i, t}^{p}\right)$. 


$$
c u_{i, t}^{\text {eval }}=c u_{t}^{\text {base }} x_{i, t}^{c} i_{i, t}^{p}
$$

During the policy experiments, capital firms may receive subsidies $\left(s u b_{i, t}\right)$, the details of this process are described in the next section. In the case a capital firm received subsidies, it spends as much of them as possible. This means that if $c u_{i, t}^{\text {eval }}<s u b_{i, t}$, the firm checks if it would be able to finance the costs of the next higher strategy from the list with the subsidy alone. It then repeats this process until the highest possible strategy, which can be financed by the subsidy alone, is found and sets its effective strategy $\left(i_{i, t}^{e}\right)$, which is the one that is actually implemented, to this value.

If on the other hand a firm does not have enough funds (own funds plus eventual subsidies) to finance the cost of the originally planned upgrade $\left(c u_{i, t}^{\text {eval }}\right)$, it reduces the effective strategy by one step and calculates the cost of the adjusted plan. This process is repeated until the cost of the reduced plan are affordable, or the effective strategy is reduced to doing no upgrades at all $\left(i_{i, t}^{e}=0\right)$.

The firm then calculates $c u_{i, t}$ analogous to $c u_{i, t}^{\text {eval }}$, substituting the planned strategy $\left(i_{i, t}^{p}\right)$ with the finally chosen strategy $\left(i_{i, t}^{e}\right)$. If an upgrade is purchased, the firm's current emission coefficient is reduced by the innovation improvement parameter $\alpha_{19}$, weighted with the effective strategy, implying future upgrades will be less effective and that production will never be completely emission free.

$$
\beta_{i, t}=\beta_{i, t-1}-\beta_{i, t-1} i_{i, t}^{e} \alpha_{19}
$$

As a modeling simplification, the funds required for the upgrades, including eventual subsidies, are transferred to a regional R\&D-fund, which itself redistributes these gains to the regional population analogous to the distribution of firms' profits.

Mines invest in innovation based on the same rules and thus keep a list of other mines which are monitored and eventually imitated. The upgrades that mines purchase improve the pollution rate $\left(\gamma_{i, t}\right)$, which affects local pollution instead of emissions (see Appendix 4, Eqs. 119-121). We assume the cost of reducing local pollution, but especially in partially reducing the negative ramifications for the mine workers, to be less expensive for mines, thus for mines the cost upgrade parameter $\alpha_{18}^{\text {mine }}$ replaces $\alpha_{18}^{\text {cap }}$ in Eq. 20. Furthermore, mines can receive subsidies, just like capital firms. The price for the upgrades is added to an R\&D fund in the Global South.

Both mines and capital firms may update the list of monitored firms that is used during the innovation process every three months in two steps. First, one firm that is not active any more, i.e., that has no workers left, can be replaced by a randomly selected other firm of the same type. Second, with a $25 \%$ chance, one randomly selected firm from the list can be replaced with a randomly selected one of the same type that is currently not part of the list, but only if this new firm has a higher profit rate than the old one.

\subsection{Policy experiments}

We test different policy scenarios aimed at mitigating the social and ecological costs of resource extraction and global production chains. The policies are inspired by the proposal made by Kapeller et al. (2016). A global institution, the civilized 
market institution (CMI), is implemented, which sanctions capital firms for producing global emissions and mines for polluting the local environment and risking the health of their workers. Two main mechanisms are evaluated, the first is the sanctioning mechanism, and the second one is a subsidy scheme, where the collected sanctions are redistributed to the capital firms and mines as subsidies tied to the purpose of investing into innovation. Both mechanisms are outlined in the following.

\subsubsection{Sanction mechanism}

The CMI sets a base fine for each region $\left(f_{R, t}^{b a s e}\right)$, based on the price of the firms' products. Thus, in the North, the base fine equals the current mean capital price $\left(\overline{p c}_{t}\right)$ times the sanction-level parameter $\alpha_{20}$, and in the South it equals the current mean resource price $\left(\overline{p m}_{t}\right)$ times $\alpha_{20}$ :

$$
\begin{gathered}
f_{R=N, t}^{\text {base }}=\overline{p c}_{t} \alpha_{20} \\
f_{R=S, t}^{\text {base }}=\overline{p m}_{t} \alpha_{20}
\end{gathered}
$$

All capital firms and mines respectively are fined individually $\left(f_{i, t}\right)$ depending on the emissions or pollution they caused in the last period:

$$
\begin{gathered}
\text { Capital firms }: f_{i, t}=f_{R=N, t}^{\text {base }} e_{i, t} \\
\text { Mines : } f_{i, t}=f_{R=S, t}^{\text {base }} \text { pol }_{i, t}
\end{gathered}
$$

The CMI collects all fines in separate accounts for each region $\left(f u n d_{R, t}\right)$.

\subsubsection{Subsidy scheme}

We test four subsidy schemes, which differ in the amount of money that is redistributed to the capital firms and mines. Nevertheless, subsidies are always linked to the condition to exclusively use them for innovation upgrades. As elaborated in section 3.7, if a capital firm or mine receives a subsidy, it will use it for innovation only and will spend as much of it as possible. This means that it chooses the most effective innovation strategy that can be financed with the subsidies, even if the originally intended innovation strategy would have been less effective in reducing emissions or pollution respectively.

The four schemes:

1. No subsidies: The CMI does not pay subsidies. The collected fines are distributed to the households of the respective regions, in the same manner as firms redistribute profits.

2. Subsidies: The fines collected in the Global North $\left(\right.$ fund $\left._{R=N, t}\right)$ are distributed among the capital firms, and respectively the fund $d_{R=S, t}$ is distributed among all mines. They receive a share of the subsidies $\left(s u b_{i, t}\right)$ in relation to the firm's rela- 
tive size, i.e. their machine capacity in relation to the total machine capacity of the whole sector:

$$
\begin{gathered}
\text { Capital firms : } s u b_{i, t}=\frac{x_{i, t}^{c}}{\sum x_{i, t}^{c \_c a p}} \text { fund }_{R=N, t} \\
\text { Mines : } s u b_{i, t}=\frac{x_{i, t}^{c}}{\sum x_{i, t}^{c \_ \text {mine }}} \text { fund }_{R=S, t}
\end{gathered}
$$

3. North-South transfer: A share $\left(\alpha_{21}\right)$ of the money collected in the Global North is transferred to the Southern fund, with $\alpha_{21}=0.25$. The scheme aims to mitigate the effects of unequal exchange by making the Global North responsible and sensitive to protecting labor and the environment in the South.

$$
\begin{gathered}
\text { fund }_{R=N, t}^{\prime}=\text { fund }_{R=N, t}\left(1-\alpha_{21}\right) \\
\text { fund }_{R=S, t}^{\prime}=\text { fund }_{R=S, t}+\text { fund }_{R=S, t} \alpha_{21}
\end{gathered}
$$

These adjusted funds are then distributed to capital firms and mines as subsidies, following Eqs. (26) and (27).

4. State grant: The funds of the CMI are strongly increased by the regional governments by the grant-parameter $\alpha_{22}$. This scheme aims to explore effects of a huge increase of previously set subsidies through public investment, though unlikely politically achievable. Again, the adjusted funds are distributed to capital firms and mines following Eqs. 26 and 27.

$$
\begin{gathered}
\text { fund }_{R=N, t}^{\prime \prime}=\text { fund }_{R=N, t}\left(1+\alpha_{22}\right) \\
\text { fund }_{R=S, t}^{\prime \prime}=\text { fund }_{R=S, t}\left(1+\alpha_{22}\right)
\end{gathered}
$$

\section{Computational simulation: Policies, settings, results and discussion}

The following section presents and discusses results of simulation experiments conducted with the following numbers of agents per region: 10000 households, 250 consumption good firms, one bank and one government. Furthermore, the Global North features 50 capital firms and the Global South 50 mines. Please see Appendix 2 for other simulation settings and parameters and Appendix 3 for a separate simulation experiment that is varying different state grant parameter settings $\left(\alpha_{22}\right)$. The simulated time horizon extends over 480 artificial months, i.e. 40 years.

Following Maechler and Graz (2020), there are significant limits for the substitution of risk for uncertainty, especially with regard to climate change and natural disasters. There is a crucial quest of introducing new institutions capable to "absorb 
Table 1 Policy packages

\begin{tabular}{lllll}
\hline & No subsidies & Subsidies & North-South transfer & State-grant \\
\hline No sanction & none & & & \\
Low sanction & low & low+sub & low+transfer_s & low+gov_sub \\
High sanction & high & high+sub & high+transfer & high+gov_sub \\
\hline
\end{tabular}

uncertainty into manageable risk" (ibid.). This quest is addressed along the global civilized market institution (CMI) with the direct aim to protect labor and environment in value chains. We test the evolutionary policy proposal previously discussed via a combination of different sanction and subsidy schemes, resulting in combined policy packages as given in Table 1 (see section 3.8. for details). Different acceleration rates in the increase and impact of natural disasters are assumed and we present three disaster scenarios on behalf of this rate (via variation of $\alpha_{16}$, see 3.6 and Appendix 2) in order to express different ordinal levels of climate change's endogenously changing impact. Scenario (A) represents a relatively slow accelerating rate of natural disasters, (B) a faster rate and (C) an extreme case with a very high acceleration of disasters.

We will thus present the results of some focal measures of combining the 9 policy packages with the three disaster scenarios yielding 27 experiments, with each experiment being repeated 100 times to account for the stochasticity of the model. As shown e.g. in Rengs et al. (2020), models of this scope inevitably lead to initial adaption processes of the self-organizing markets due to random initial conditions, which do not reflect the later systemic behavior. To be able to more clearly discern these from the results of the experiments proper, scenarios and policy packages are effective only after ten years of simulation. In the following, we will thus exclude this burn-in phase of the first ten years and only show the thirty years of the experiment proper. Time series show annual aggregates of the respective average values across the 100 repetitions, with the shaded area around these indicating their distribution from the 10th to the 90th percentile (extreme outliers are cut out thereby). Discussion of simulation results follows an evolutionary comparative approach with a focus on ordinal categories, different levels of change and complex path-dependent dynamics.

\subsection{Technical and social-ecological innovation mechanisms}

Capital firms' innovation activities, addressed here, involve technical improvements in production facilities, equipment and machinery in order to reduce carbon emissions directly during production. Technological advances are not to be considered as radical innovations somehow resolving carbon output out of the blue, but rather piecemeal changes of recombining existing instrumental means to pragmatically reduce emissions wherever possible. Capital firms innovate within a spectrum of potential upgrade levels along the mechanisms explained in 3.7. 


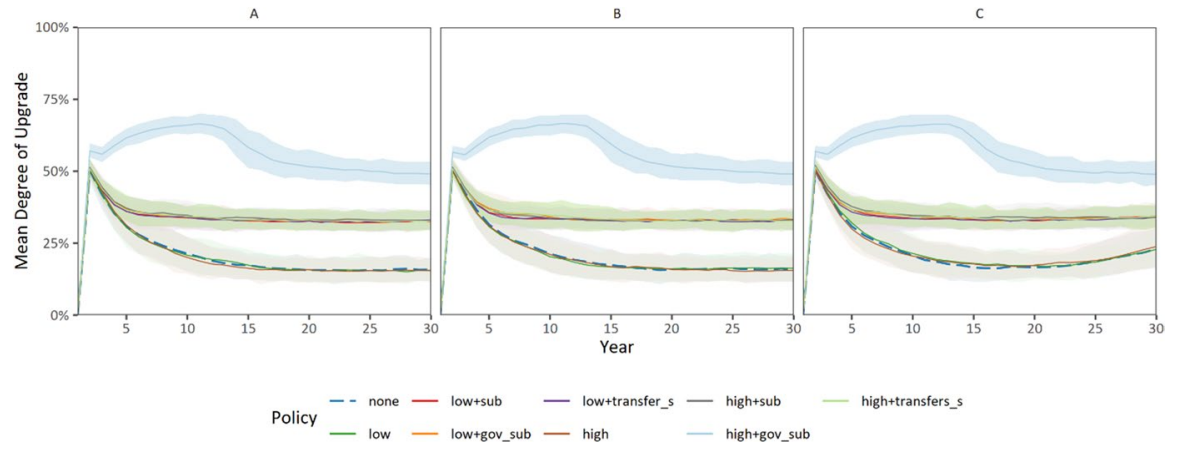

Fig. 2 Mean innovation strategies of capital firms (unweighted)

For capital firms, we may identify three qualitatively distinct innovation trajectories dependent on combinations of sanctions and subsidies, see Fig. 2. The lowest trajectory represents the cases "none", "low" and "high" which converge to $16 \%$ after 30 years for scenarios A and B, while scenario C first shows a similar behavior that changes after 20 years. $^{2}$ This slight (eventual) upswing of effective innovation strategies is a direct result of capital destruction induced by natural disasters, strongly reducing upgrade costs sequentially. As we show in sub-section 4.3 , it is in fact the result of the economy in both regions breaking down, due to lost machine capacities after climate-induced disasters. Thereby, firms may realize their innovation intentions to a higher degree, although without any effect anymore. In general, the figure shows that policy packages without subsidies do not perform any better than the baseline case ("none") in our model. The reason is that even very high fines do not have a huge effect on the overall profitability of the firms as all firms are subject to at least some degree of fines. Such policies would thus fail in light of similarly structured firms that follow the most profitable competitor where innovation is incremental instead of disruptive.

The second trajectory we are observing encompasses a greater set of mechanisms: "low+sub", "low+gov_sub", "low+transfer_s", "high+sub" and "high+transfer_s". Capital firms converge here on an innovation path around 33\% in all scenarios. Eventually, only the additional state grant (on top of the high-sanction financed one - "high+gov_sub") may shift capital firms onto a higher innovation path above $50 \%$ of the upgrade level spectrum. The state grant policy package represents the highest upgrade potential in comparison to all other policy mixes. The higher the subsidies are, the more will be invested in upgrades in the first response. More upgrades mean less emissions, which will reduce future sanctions. Fewer sanctions will result in less subsidies. The higher these initially are, the faster the reduction of emissions, sanctions and subsidies will take place. However, in total the different disaster scenarios $(A, B, C)$ do not alter the shape of the innovation trajectories significantly.

\footnotetext{
2 The thick line in the Figures represents aggregate averages and the shaded area around it, the 10th and the 90th percentile.
} 


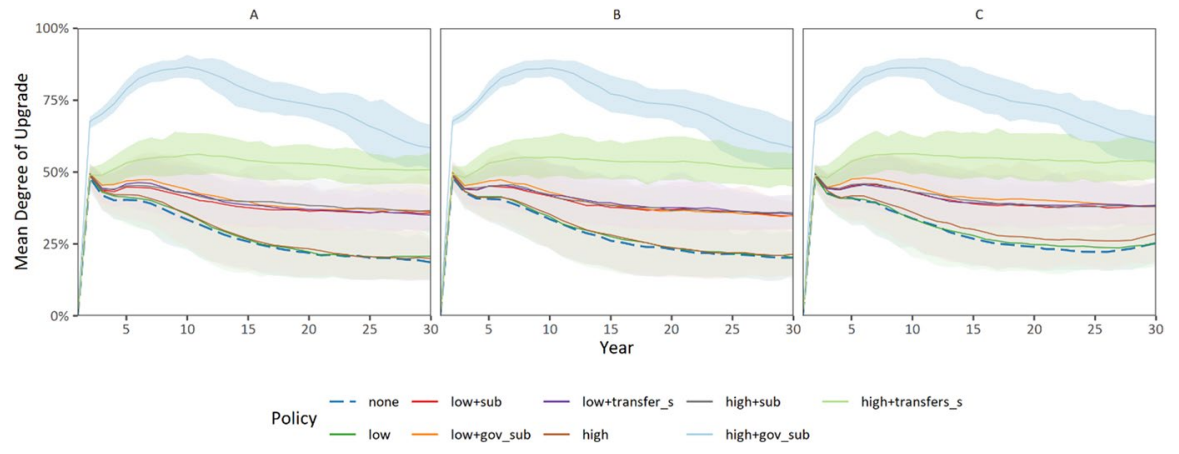

Fig. 3 Mean innovation strategies of mines (unweighted)

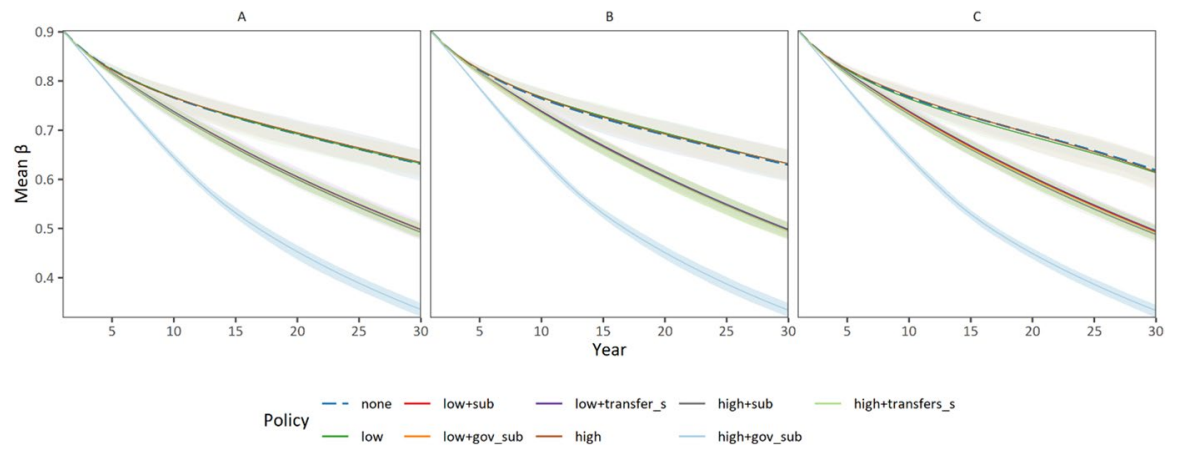

Fig. 4 Mean emission rate $\left(\beta_{\mathrm{i}, \mathrm{t}}\right)$ of capital firms (unweighted)

The situation in mines is different, since the innovation activities target protection of labor and local environment instead of reducing emissions. Figure 3 shows innovation trajectories for mines, which are less differentiated than those of capital firms. We observe four different innovation pathways, the lowest again containing "none", "low" and "high" converging around $20 \%$ for scenarios A and $\mathrm{B}$; and $25 \%$ for $\mathrm{C}$ after 10 years. At about 35\%, policies "low+sub", "low+gov_ sub", "low+transfer_s" and "high+sub" can be identified.

High subsidies in conjunction with the transfer mechanism from capital firms to mines (high+transfer_s) enables the latter to upgrade $50 \%$ of their machines after 30 years. The best performing policy is again given by the additional state grant. The upgrade potential of mines is generally higher than that of capital firms, although as mentioned before, the associated costs and meaning of the upgrades are different. Policies are not significantly affected by the different disaster scenarios $(\mathrm{A}, \mathrm{B}, \mathrm{C})$ as in the previous case.

Capital firms constantly improve their technology $(\beta)$, which consequently develops along the three distinct paths identified before. As there is a technological limit to the reduction of emissions, the trajectory would eventually flatten but never reach zero. As can be seen in Fig. 4, this not only leads to less carbon-intensive means of 


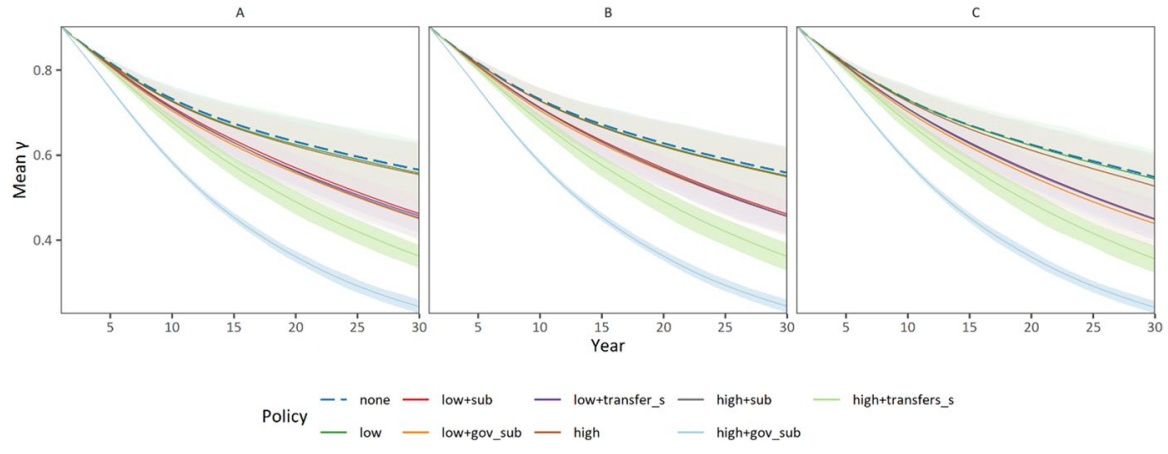

Fig. 5 Mean local pollution rate $\left(\gamma_{i, t}\right)$ of mines (unweighted)

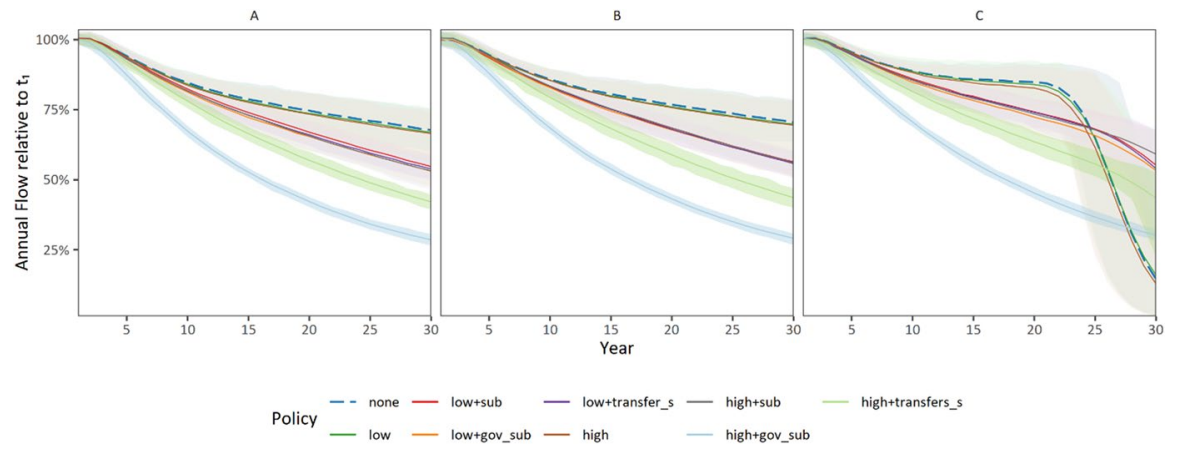

Fig. 6 Annual local pollution of all mines, in $\%$ from the starting value at $\mathrm{t}=0$

production after 30 years, but moreover, especially in the case of high subsidies that are increased by state grants (high+gov_sub), to reaching a better technology much earlier. As we will show in section 4.2, this may lead to qualitatively different trajectories with regard to global emission stock levels and thus disasters.

Similarly, regarding mines, we may observe the evolutionary policy effects by plotting mean $\gamma$, which indicates the degree of technical and social-ecological means to protect labor and the local environment (see Fig. 5). Again, these follow four distinct pathways, where subsidies increased by state grants thus lead to the most fitted means of social-ecological protection, followed by transfers from capital firms on top of high subsidies. While only providing subsidies leads to a less strong, but still significantly better effect than the baseline case and policies not providing subsidies.

\subsection{Social-ecological implications}

In the previous section we discussed the implications of the policy packages on firms' innovative behavior, whereas we turn to their effects on labor and the environment now. Figure 6 focuses on the mitigation of local pollution produced by mines. 


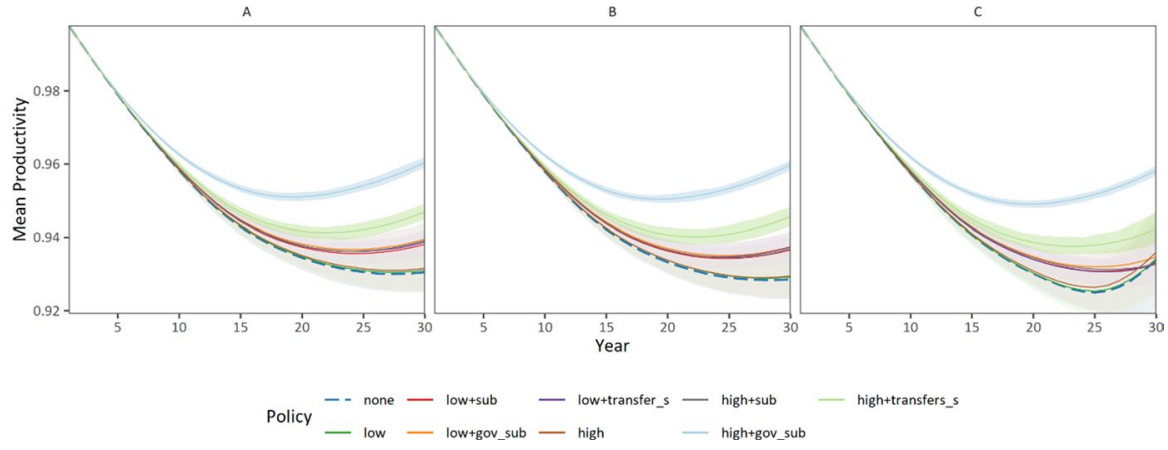

Fig. 7 Mean agent productivity of the whole agent population of the Global South

Among the four distinct innovation trajectories for mines, "high+gov_sub" performs best in terms of mitigation, indicating that a high sanction combined with the state grant would be most effective, if politically achievable and viable. Nevertheless, additional transfers from capital firms to mines represent most probably the most convincing policy option (second-best outcome), since transfers are completely recycled from funds gained from raised sanctions. Disaster scenario $\mathrm{C}$ with the highest acceleration of natural disasters shows a drastic reduction of annual local pollution in the low sanction mechanisms. As already indicated, this is not a positive result of the policies, but the consequence of a total breakdown of the economy. When mines reduce or stop production due to a drop in demand, pollution will of course stop, too.

Eventually, local pollution affects workers' health in the Global South, thereby also reducing individual productivity of workers employed by mines as shown in Fig. 7. The combination of the improvement of mines' labor and environment protection and the eventual retirement, i.e. replacement of workers in the South, in the long run leads to improvement of overall health. Again, this happens much earlier and the reaction is stronger with the aforementioned policy packages, as the initially worst behavior of the lowest trajectory causes the sharpest turnaround in scenario $\mathrm{C}$, though it comes at the cost of an economic breakdown, which would very likely affect health even more, but is not accounted for in this model.

Figure 8 shows annual emission flows induced by capital firms, where again the three distinct trajectories are observable. The highest subsidies accompanied by state grants reduce annual emissions to half of the initial level over 30 years. Again, the sharp drop of emissions in the otherwise worst policies in scenario $\mathrm{C}$ is a result of the economies' breakdown.

As emissions accumulate over the years, reducing emissions obviously only reduces the inflow, which is only partially effective when assuming a fixed outflow (e.g. natural binding of emissions). As indicated by Fig. 9, for the policy packages without subsidies, the inflow hardly reduces, with the exception of scenario $\mathrm{C}$, where the global emission stock even reaches critical levels, which eventually results in a sharp turn-around due to the breakdown. The other policy packages lead to an 


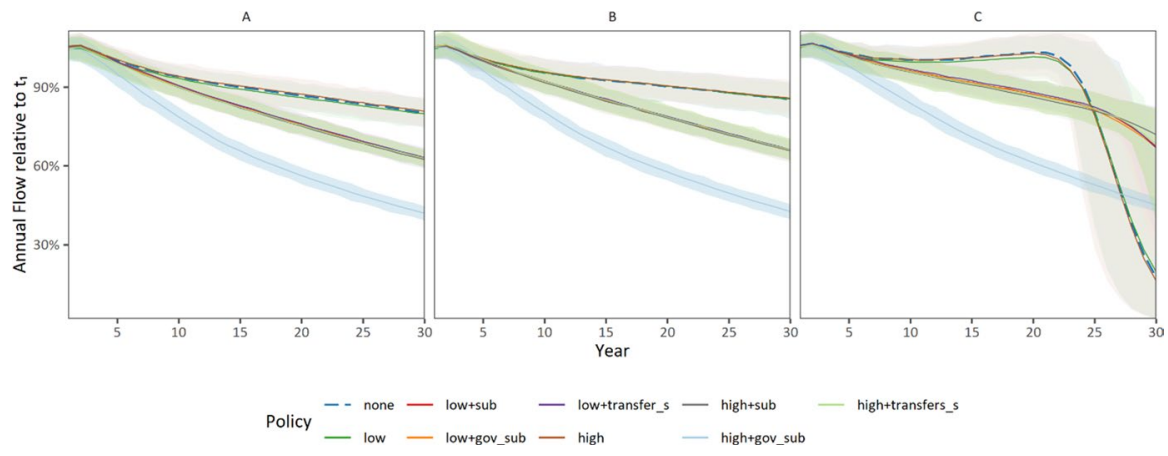

Fig. 8 Global emission flow caused by capital-firms, in $\%$ of the starting value at $t=1$

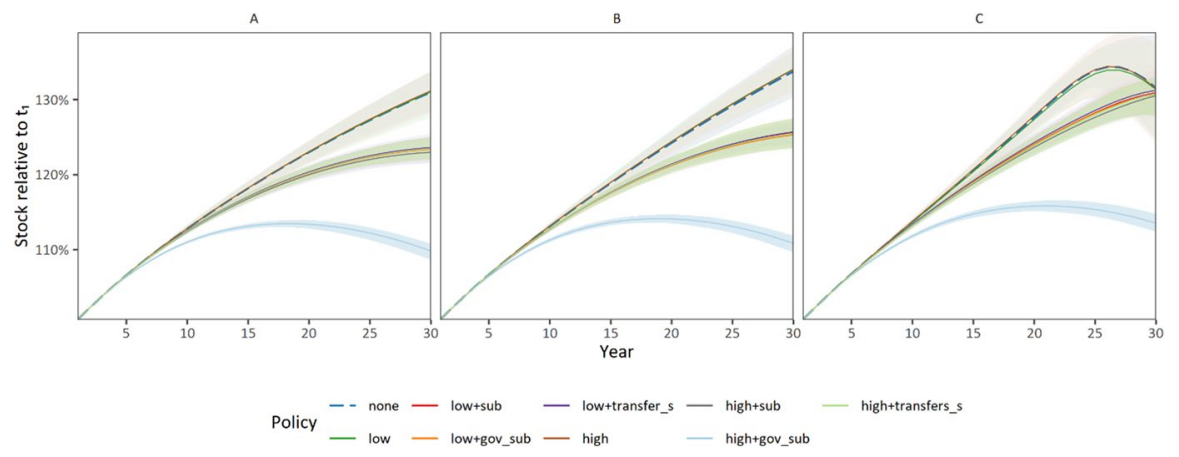

Fig. 9 Stock of accumulated global emissions, in $\%$ of the starting value at $\mathrm{t}=1$

eventual flattening of the curve, which happens at a later point in time for the more severe disaster scenarios. The only severely different trajectory is the policy which includes additional state grants, which performs significantly better than all other policies in all disaster scenarios, because the technological improvement happens much earlier, before the acceleration of disasters really kicks in.

This added value becomes even more visible when looking into the development of destroyed machine capacities on behalf of climate-induced disasters. In our worst disaster scenario (C) the damage reaches 5-7\% of total machine capacity destroyed each year (aggregated for both regions) for all policies except the one with high subsidies and state grants. Only the latter policy seems to be effective enough to avoid emissions early enough and thus mitigating the total damage on machine capacities in the long run. This is also the case for the average disaster scenario (B), but much less expressive. Otherwise, in the most optimistic scenario A, there is not much difference in terms of the damage caused.

We can now see the reason for the breakdown (respectively resulting into political economic crisis) in scenario $\mathrm{C}$ more clearly. The increasing levels of emissions cause a non-linear increase in natural disasters, which accelerates even more as these cause the destruction of machines. This requires the production 


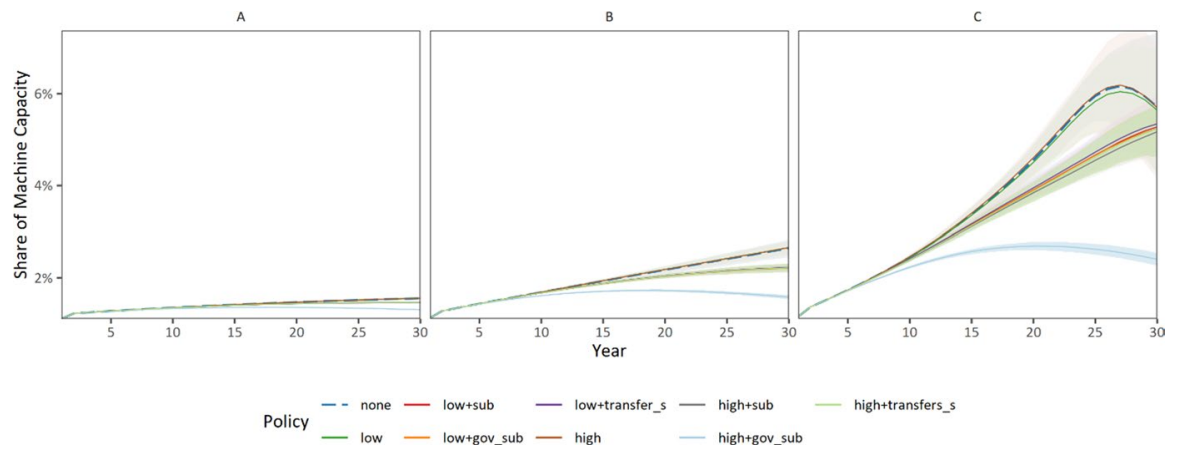

Fig. 10 Relative destruction of machine capacity, in relation to total machine capacity

of even more machines to replace them, which is a self-reinforcing process (vicious loop), where the additional emissions caused by the increase in production exceed the effect of reducing emissions by innovation. ${ }^{3}$ In the case of those policies without subsidies, at some point so much production capacity of capital firms or mines is destroyed, that they cannot replace machines quickly enough. This at some points leads to a shortage of production capacity at mines and capital firms, which self-reinforces and quickly leads to a complete breakdown of the economy. But this development will not reduce disaster frequency very quickly, even if the inflow of emissions would reduce to zero in the case of a full stop of the economy, because the stock of accumulated emissions has reached very high levels. Further simulations with higher acceleration of natural disasters than scenario $\mathrm{C}$ have shown, that even the medium trajectory policies, which do provide subsidies, would get into such a vicious cycle in the same timeframe too, while the policies with the worst trajectories would end up in a breakdown even sooner. The much broader stochastic distribution bands around the badly performing trajectories in scenarios C, in Fig. 10 as well as the other figures, do not result from qualitatively different outcomes for those experiments, but simply from a different timing of the onset of the total breakdown. Thus, in the long run, all policies that do not succeed in establishing a turn-around of the stock of aggregated emissions soon enough, will end up in a breakdown.

\subsection{Economic implications}

As shown in the following, the presented policy packages themselves have hardly any significant negative economic implications while still protecting labor and the environment in global value chains. We start by looking a bit closer into some meso level industrial sector variables.

The global value chain collapses only in scenario (C) if countermeasures are not taken at sufficient magnitude. After 20-25 years, the loss in machine capacities

\footnotetext{
${ }^{3}$ Compare Rengs et al. (2020) indicating the emergence of similar dynamics, though in a different model.
} 


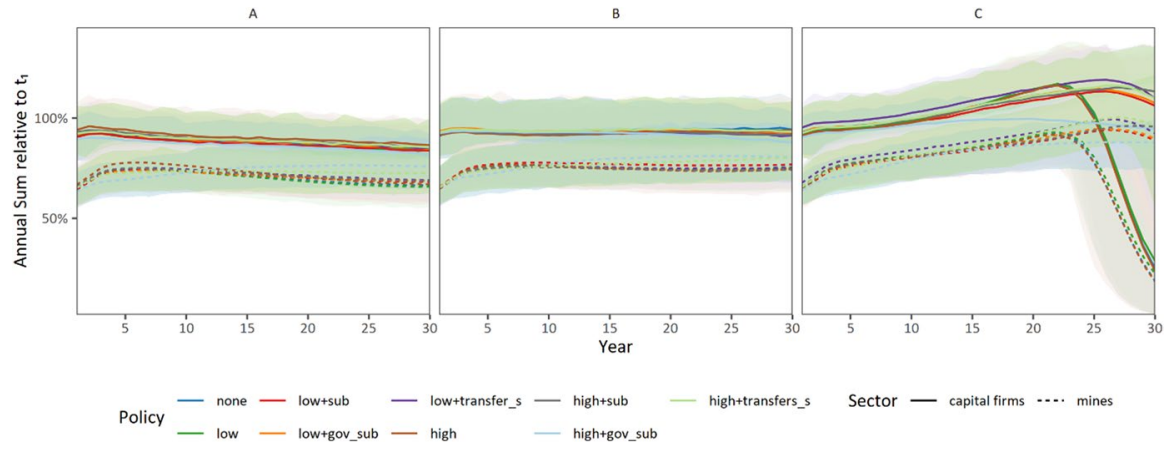

Fig. 11 Exports of capital-firms and mines, in \% of capital-firm exports at $\mathrm{t}=0$

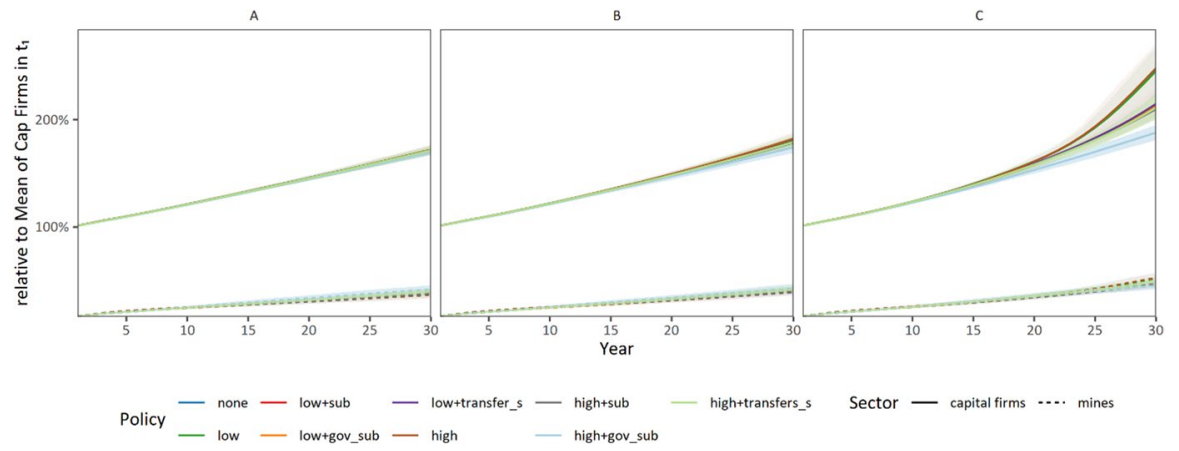

Fig. 12 Prices of goods sold by capital-firms and mines

(Fig. 10) leads to a freefall of production in both sectors as shown in the previous section. Figure 11 shows sector exports from mines (South) to capital firms (North) as well as from capital firms (North) to mines and consumption good firms (South). If there are no policy measures taken at all, or just low measures (without additional transfers or state grants) the value chain cannot be stabilized. Capital firms react to the disrupted value chain and the crisis-prone situation with an increase in prices, as a direct response to damaged machine capacities (see Fig. 12).

Overall, the capital and resource sectors have very different price levels, reflecting the situation of unequal exchange in global value chains. Capital firms have more market power and are able to extract higher surpluses from importing resources at very low prices, which are only possible due to the lower wage regime in the South in the first place.

The response of increased capital prices due to increased demand and at the same time less available machines in scenario (C) is seconded by firing workers in both intermediary sectors. Figure 13 shows the development of their employment. Employment in the labor-intensive mining sector is higher when the climate-induced disasters destroy machines, as more resources are needed to build more machines. Furthermore, policies which neglect to alleviate the negative 


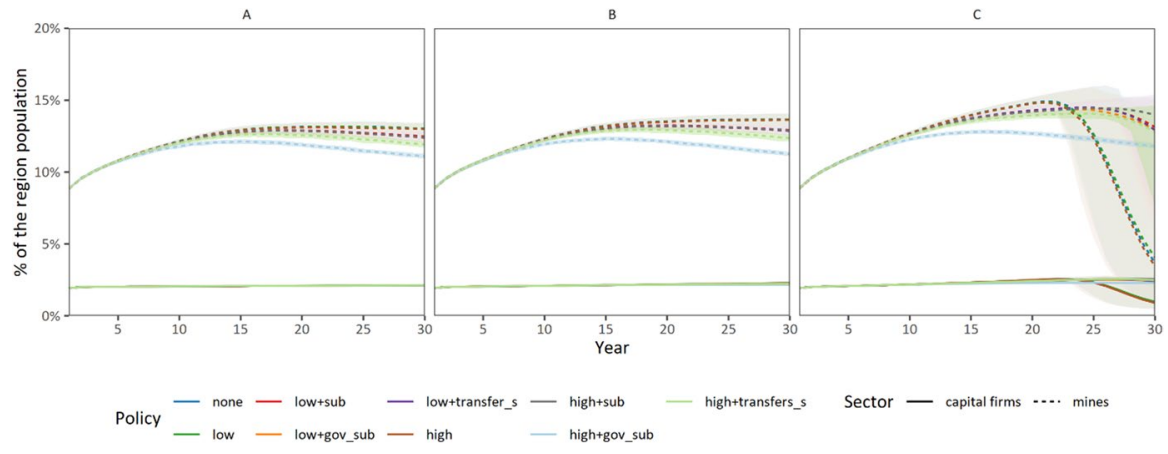

Fig. 13 Employment in the capital-firms sector and mine sector, in $\%$ of the total population per region

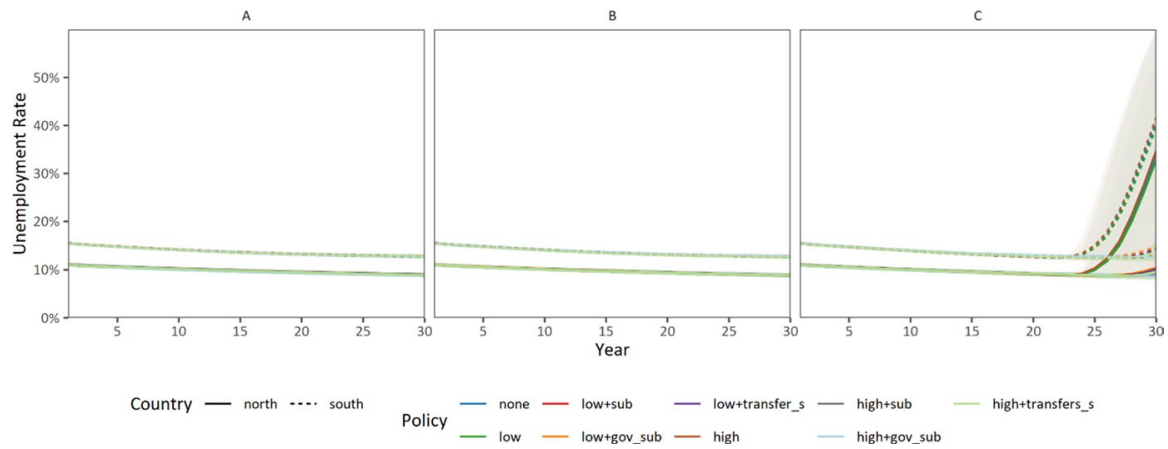

Fig. 14 Unemployment in the Global North and Global South, in \% of total population in each region

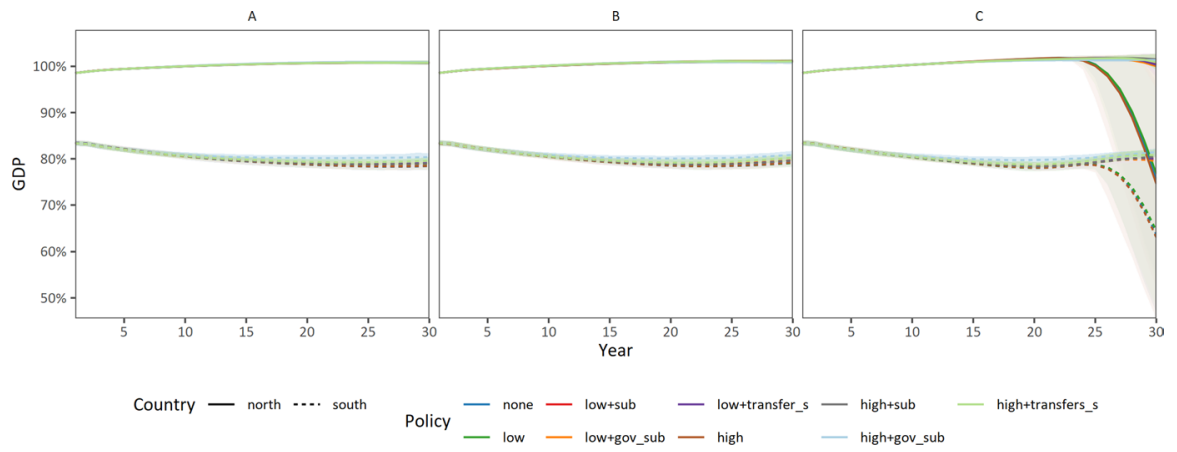

Fig. 15 Real GDP in the Global North and Global South, in \% of total population in each region

health effects of working in a mine also result in higher employment in the mining sector due to the loss of productivity. Of course, serious problems arise once climate-induced disasters cause a breakdown of the economy, if not compensated by high subsidies and state grants. With the exception of the loss of worker 
productivity the same is true for capital firms, but as the capital good production is much less labor intensive, it is much smaller in absolute terms.

But the effects are not only problematic for the intermediary sectors. Macroeconomic implications are given via the aggregated unemployment for both regions (Fig. 14) and the development of real GDP (Fig. 15).

In general, unemployment is higher in the Global South, but stable. The evolutionary policy mechanisms introduced obviously do not affect employment negatively, even over a long simulation time horizon in the presented model. This is crucial, since institutionalized policies are often regarded as too disruptive for the dynamics of the circular flow. Even in scenario (C), with a high acceleration rate of climate-induced disasters and heavy damage on machine capacities, the tested policies may keep employment stable in both regions, if high subsidies are operationalized, at best in combination with transfers from capital firms to mines or even with a state grant of the institutionalized labor and environment protection fund.

Real GDP develops in a very stable way (Fig. 15) and is thereby mirroring the development of unemployment. GDP is far smaller in the South, but both regions' real GDP is not affected by the tested policy packages. This notion implies that the proposed policies may lead to a successful evolutionary adaptation of the whole system in mitigating the uncertain damage done by local pollution on the one hand and carbon-intensive production by capital firms on the other hand. Still, however robust complex adaptive systems may be, they may still break apart abruptly in case of maladaptation, in our case given by the non-recycled sanction policies in scenario (C).

\section{Concluding remarks}

We present a multi-sector, multi-regional agent-based economic model containing a global value chain in this research article. The approach is novel and unique since it addresses characteristics and adaptation problems of the fragmented world economy via an artificial global value chain crossing two political economic regions and containing three sectors: (1) mining in the Global South, (2) capital good production in the Global North and (3) consumption good production and retailing in both regions. The flow of the value chain starts with resource extraction of raw materials and primary input in mines of the Global South, which is only bought by capital firms in the Global North. Mines adapt their production on behalf of changes in the individual demand for resources by capital firms, which themselves manufacture machinery for competitors as well as mines and consumption good firms in both regions. The latter firms adapt their machine capacities and labor input dependent on individual demand of domestic consumers in the North and South. All three sectors are completely disaggregated and adapt in two macroeconomic systems.

The stated problem is of global evolutionary political economic relevance. Labor in the mines of the South is exploited with bad working conditions and low wages, and environmental damage is caused at the place of extraction, which permanently affects the productivity of workers. Cheap resources are exported to the North where profits can be made 
with highly demanded complex machinery, manufactured with the low-cost primary input. This aspect is referred to as unequal exchange in the literature and creates a double burden for regions of the Global South. On the one hand, it makes those regions economically dependent on the rules of free international trade, resulting into lower wages and exploited labor, on the other hand, the local environment is heavily damaged due to large amounts of solid waste and the use of toxic chemicals. This second burden threatens not only the ecosystems in the local areas of the mines but also the health of the workforce and the local population. Moreover, the production processes in capital firms are emission-intense and therefore fuel anthropogenic climate change. Among other causes, it contributes to higher frequencies of natural disasters on a worldwide scale, which destroy physical capital worldwide and threaten human lives.

In our agent-based economic model, we test two different evolutionary political economic policy mechanisms as a response to (i) the problem of local pollution of mines and resulting impacts on workers' health and (ii) the damage to firms' production capital induced by natural disasters. The policies are both operated by a global "civilized market institution" that is charging fines and redistributing funds for innovation activities addressing the raised problems in the North and South. A series of policy packages is investigated in simulation experiments. The main outcome of the study is that sanctions, regardless of their level, alone are not effective, neither in countering unequal exchange, nor in avoiding damage caused by natural disasters. Only in combination with subsidies for innovation activities, which are labor protection and reduction of local pollution in mines as well as reduction of carbonemissions in capital good production, the value chain can become more sustainable and just over the long run.

We investigate three policies where first, subsidies are financed only from raised sanctions, second, subsidies are increased in the South via additional transfers from Northern capital-firms to mines and third, subsidies are significantly increased with a state grant. With the exception of the state grant scenario, all cases are cost-neutral for public finances, since the subsidies are funded via the sanctions only. The first evolutionary policy package already allows mitigating pollution and emissions at such extent that even in an extreme disaster scenario, the value chain can be stabilized and thus also both economies within the medium and long-run. The best performing policy in terms of social-ecological implications is given by the additional state grant, put on top of sanction-financed subsidies. Climate change induced damage as well as local pollution can be decreased substantially. In the presented experiment, we chose the state grant to considerably increase the funds available to the CMI to highlight the theoretical potential. Nevertheless, the model yields comparable results for other values of $\alpha_{22}$, as can be seen in the experiment presented in Appendix 3. Still, it is important to highlight that this policy package may face problems with regard to political achievability, since not all governments will be able to acquire a mandate for such a significant fiscal expansion in that direction, or may intentionally refrain from that option. Moreover, other unintended impacts of using public finance cannot be analyzed with this model. In terms of effectiveness as well as political economic implications, the policy which partially transfers subsidies to mines delivers the most promising results. Results have shown that capital firms still invest in reducing carbon emissions on the same level even with a somewhat lower subsidy. The reason 
is that the magnitude of the transfers is low enough that the policy is not shifting capital firms on a higher damage trajectory, but otherwise high enough to boost labor protection and mitigation of local pollution in mines of the South, due to the difference in the cost structure via the lower wage regime. Eventually this policy delivers very good results in terms of health recovery, reduction of local pollution flows and mitigation of climate change. However, the models' firms feature simple strategic behavior, driven by profit motives only, realized in the form of incremental adaptations. As such, they have no intrinsic motivation to reduce emissions, local pollution flows and to protect labor. The presented results thus do not rely on optimistic assumptions of firms' strategies. Thereby, the model represents a worstcase mitigation mechanism of economies to cope with climate change.

We can highlight that the evolutionary policy packages - at best supported by additional transfers - don't have any negative impact in terms of economic implications, neither on micro, meso or macro level. We show that even with a rather minimalized effort - concerning fiscal budget neutrality - an institutional approach to the problem of unequal exchange may deliver very promising results in protecting labor and the environment. It is indeed possible to stabilize the global value chain substantially on behalf of sanction-financed subsidies for innovation activities in this direction. By charging firms in the Global North, we recognize that many of the current global challenges are predominantly impacting countries of the Global South, while the Global North profits from outsourcing pollutant industries and investing in complex and highly profitable production processes in the North. Holding multinational corporations responsible for the damage they cause is an important contribution to sustainability and equality in ecological as well as social terms. Binding due diligence rules, as proposed by the European Parliament (2021) are promising developments.

\section{Appendix 1 - Timing of Events}

One period in the simulation symbolizes one month, some events only take place once per simulated year.

\section{Monthly events:}

\section{Household consumption}

- Households decide about consumption expenditure

- Households update shortlist of vendors (consumption good firms)

- Households buy consumption goods

\section{Consumption good production}

- Consumption good firms update the production plan and adjust prices

- Consumption good firms hire or fire workers; every 2 months in the Global North

- Consumption good firms update shortlist of vendors (Capital firms), every 3 months

- Consumption good firms buy machine capacities 
- Consumption good firms produce consumption goods

\section{Resource production}

- Mines update the production plan and adjust prices

- Mines hire or fire workers

- Mines update shortlist of vendors (Capital firms), every 3 months

- Mines update shortlist of tech-imitations (Mines), every 3 months

- Mines buy machine capacities

- Mines extract resources

- Local pollution caused by the production is calculated

- Workers are affected by local pollution

\section{Capital good production}

- Capital firms update the production plan and adjust prices

- Capital firms hire or fire workers; every 2 months

- Capital firms update shortlist of vendors (Capital firms \& Mines), every 3 months

- Capital firms update shortlist of tech-imitations (Capital firms), every 3 months

- Capital firms buy resources

- Capital firms buy machine capacities

- Capital firms produce capital goods

- Emissions caused by the production are calculated

\section{Wage payment}

- Consumption good firms, capital firms and mines pay wages

- Governments adjust unemployment benefits

- Governments pay unemployment benefits

\section{Loan payment}

- Consumption good firms, capital firms and mines pay back loans

\section{Biophysical events}

- Natural disasters: Global emissions randomly cause damage to the machine capacities of some firms (consumption good firms, capital firms or mines)

- Natural reduction of emissions

\section{Annual events}

- Bankruptcy of consumption good firms 
- Consumption good firms, capital firms and mines pay taxes to the governments

- Policy experiments step I - CMI sanctions firms and pays subsidies

- Policy experiments step II - capital firms and mines can buy upgrades

- Consumption good firms, capital firms and mines adjust wages

- Consumption good firms, capital firms and mines calculate profits

\section{Appendix 2 - Simulation parameters}

The agent-based model is implemented in version 6.2 of NetLogo (Wilensky 1999), a free and open source, widely used software development kit for agent-based modelling. ${ }^{4}$ The simulation experiments were set up using NetLogo's built-in BehaviorSpace experiment management engine to repeat experiments with different random seeds. Aggregate time series data was generated directly by BehaviorSpace. Data analysis and visualization are realized using the $\mathrm{R}$ language (with the ggplot2 package).

Simulation experiments, as described in Section 4, are a combination of a policy package (none, low, low+sub, low+transfer_s, low+gov_sub, high, high+sub, high+transfers_s, high+gov_sub) and a natural disaster scenario (A,B,C). Each experiment was simulated 100 times with different seeds to account for different realizations of random factors and thus render the obtained results more robust. Reruns of identical policy/disaster combinations generally varied only slightly due to stochasticity, which underpins the high robustness of the results. Each of these runs was simulated for 480 time steps, representing months, resulting in a simulated time horizon of 40 years. ${ }^{5}$

\section{Appendix 3 - Sensitivity of the model to variations of the state-grant parameter $a_{22}$}

To examine the impact of different levels of the state-grant parameter $\alpha_{22}$, we conducted another simulation experiment. The parameters were the same as those of the main experiment as shown in Appendix 2, with the one exception of variating $\alpha_{22}$ while only taking the policy package with high sanctions and state grants (high+gov_sub) into account. The results show that variation of the level of the grant leads to comparable results as the presented experiment, where the model reacts similar to the policy packages without state grants for low $\alpha_{22}$. In the following, we present the results for the most important aggregate measures shown in the main text, with dashed lines indicating the level of $\alpha_{22}$ that was chosen in the main experiments.

\footnotetext{
4 The NetLogo source and documentation of the simulation is available under creative commons license here: https://www.comses.net/codebases/8cd6f0b3-acd2-4bb6-8b15-3677e752ef4c/releases/1.0.0/

5 See Appendix 1 for a list showing the timing of monthly and annual simulation events.
} 
Table 2 Parameter settings

\section{Households}

Length shortlist of households $\left(\alpha_{1}\right)$

Share of savings that are used for consumption each month $\left(\sigma_{1}\right)$

Firms (Cons cap mine)

Unsold stock depreciation rate for consumption good firms $\left(\delta_{1}^{\text {cons }}\right)$

Unsold stock depreciation rate for capital firms $\left(\delta_{1}^{c a p}\right)$.

Unsold stock depreciation rate for mines $\left(\delta_{1}^{\text {mine }}\right)$

New price adoption probability $\left(\theta_{1}\right)$

Capital firm specific emission intensity, starting value $\left(\beta_{i, t}\right)$

Mine specific local pollution rate, starting value $\left(\gamma_{i, t}\right)$

Production reserve stock rate $\left(\alpha_{2}\right)$

Maximum price adjustment $\left(\alpha_{3}\right)$

Excess demand rate $\left(\alpha_{4}\right)$

Capital intensity coefficient consumption good firms $\left(\alpha_{5}^{\text {cons }}\right)$

Capital intensity coefficient capital firms $\left(\alpha_{5}^{c a p}\right)$

Capital intensity coefficient mines ( $\left.\alpha_{5}^{\operatorname{mine}}\right)$

Production-technology coefficient ( $\left.\alpha_{6}^{\text {cons }}\right)$

Production-technology coefficient ( $\left.\alpha_{6}^{c a p}\right)$

Production-technology coefficient $\left(\alpha_{6}^{\text {mine }}\right)$

Maximum labor increase $\left(\alpha_{7}\right)$

Stock adjustment indifference rate $\left(\alpha_{8}\right)$

Monthly Machine capacity \& value depreciation rate $\left(\alpha_{9}\right)$

Number of capital firms on shortlist $\left(\alpha_{10}\right)$

Number of capital firms on shortlist $\left(\alpha_{11}\right)$

Resource intensity coefficient capital firms $\left(\alpha_{12}\right)$

Health-impact factor $\left(\alpha_{13}\right)$

Emission factor $\left(\alpha_{14}\right)$

Damage-impact factor $\left(\alpha_{15}\right)$

Simulation-specific acceleration $\left(\alpha_{16}\right)$ (for scenarios A,B,C)

Innovation-imitation network $\left(\alpha_{17}\right)$

Cost-upgrade parameter $\left(\alpha_{18}^{c a p}\right)$

Cost-upgrade parameter $\left(\alpha_{18}^{\text {mine }}\right)$

Innovation improvement parameter $\left(\alpha_{19}\right)$

Sanction-level parameter $\left(\alpha_{20}\right)$ (for scenarios no, low, high)

Transfer share $\left(\alpha_{21}\right)$

State grant parameter $\left(\alpha_{22}\right)$

Price adjustment parameter $\left(\alpha_{23}^{\text {cons_north }}\right)$

Price adjustment parameter $\left(\alpha_{23}^{\text {cons_south }}\right)$

Price adjustment parameter $\left(\alpha_{23}^{\text {cap }}\right)$

Price adjustment parameter $\left(\alpha_{23}^{\text {mine }}\right)$

Emission stock reduction parameter $\left(\alpha_{24}\right)$ 
Table 2 (continued)

\section{Households}

\section{Government}

Tax rate $\left(t r_{g}\right)$

Bank

Interest rate $(i r)$

Credit-lenience $\left(\nu_{1}\right)$

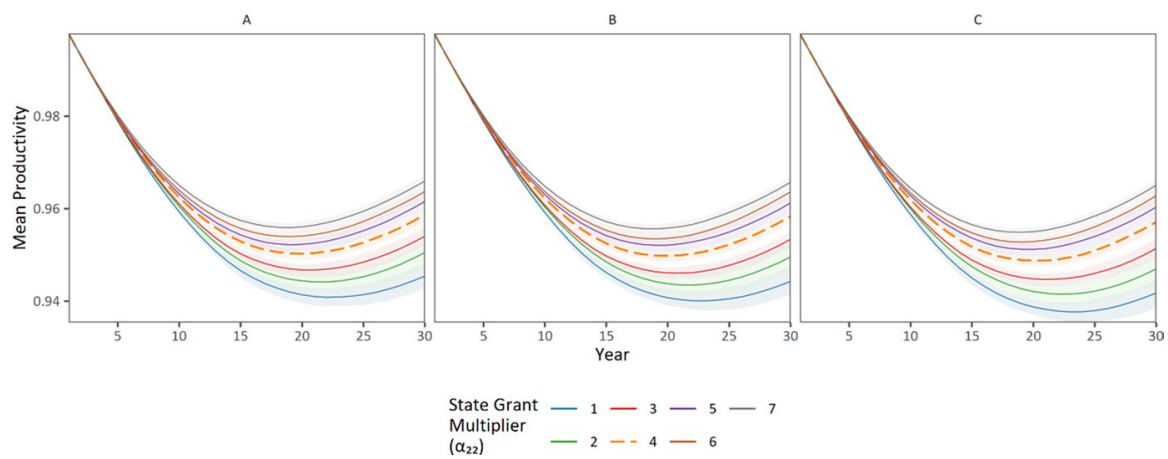

Fig. 16 Mean agent productivity of the whole agent population of the Global South

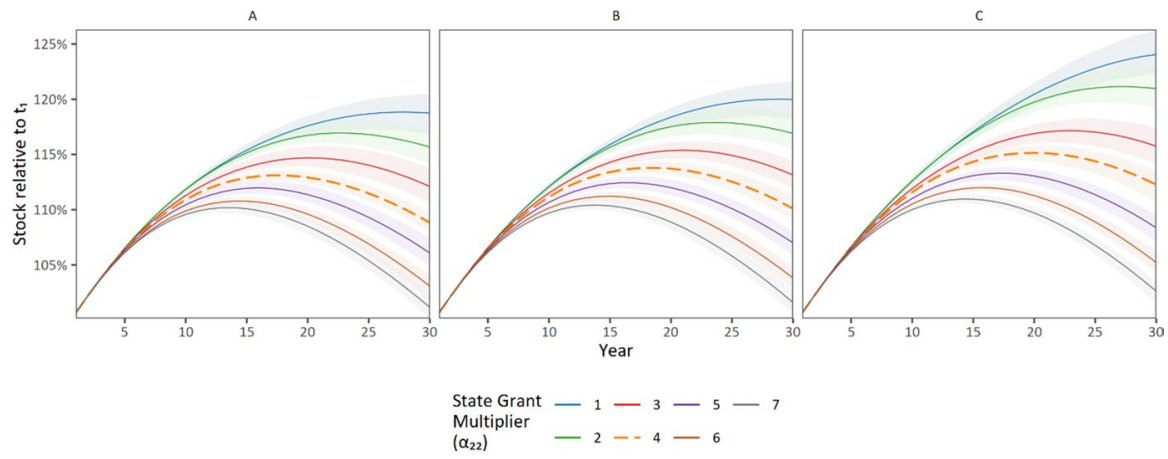

Fig. 17 Stock of accumulated global emissions, in $\%$ of the starting value at $\mathrm{t}=1$ 


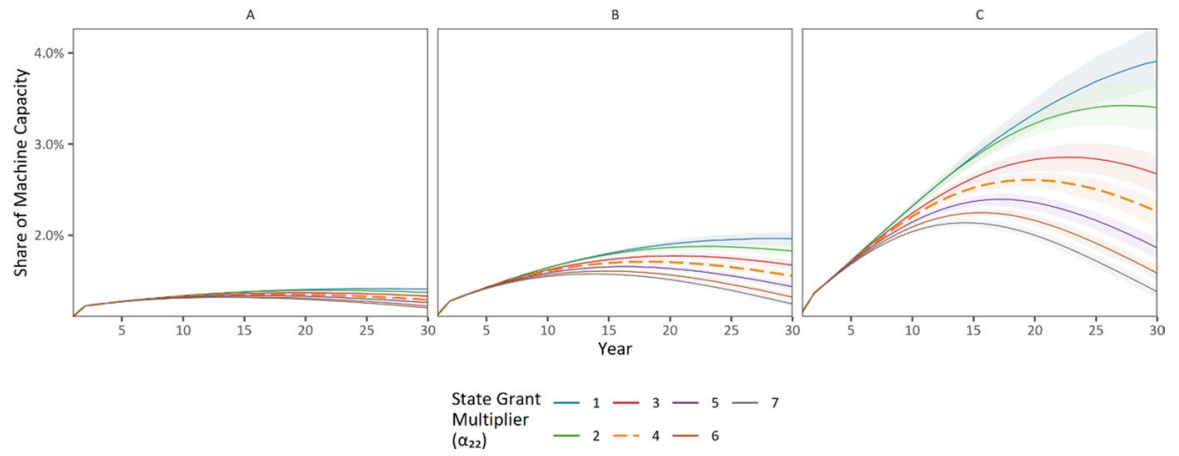

Fig. 18 Relative destruction of machine capacity, in relation to total machine capacity

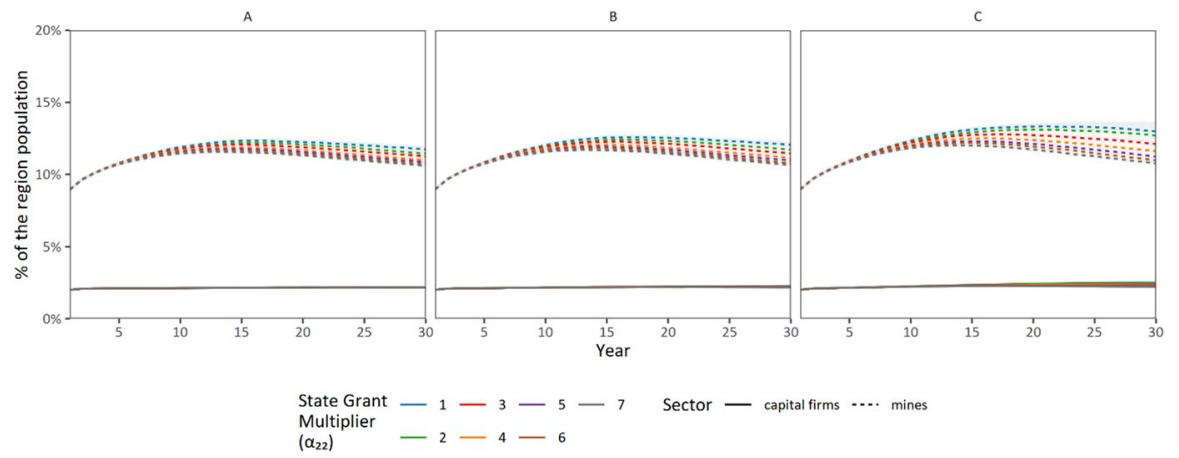

Fig. 19 Employment in the capital-firms sector and mine sector, in \% of the total population per region

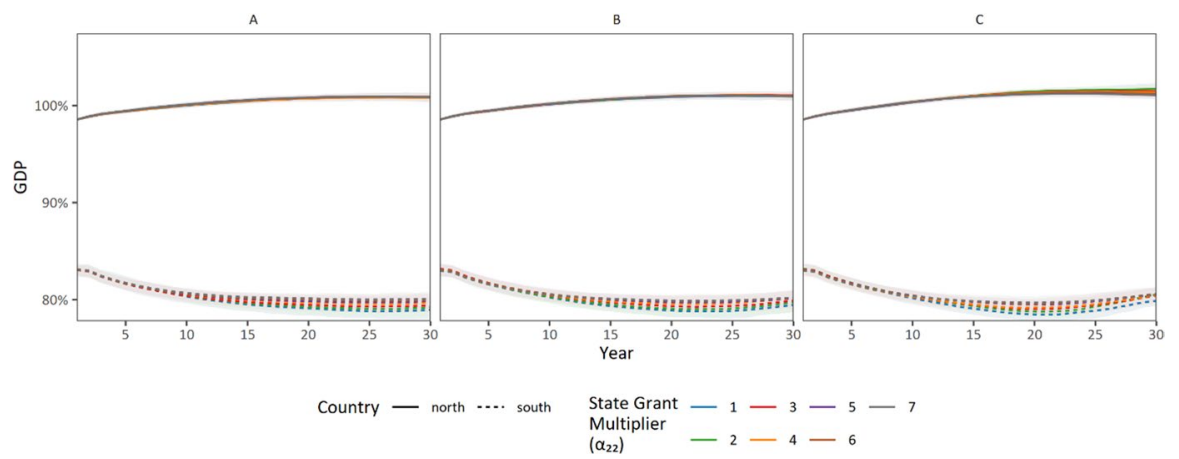

Fig. 20 Real GDP in the Global North and Global South, in \% of total population in each region 
Even low levels of the state grant would enable a reversal of the negative health effects on mine workers in the Global South, in every scenario (Fig. 16). Figure 17 shows that very high levels of the state grant might have the potential to even reach the starting level of the accumulated global emissions within the simulated period in most scenarios. Low levels of the state grant on the other hand would again perform similar or slightly better than those in the medium level trajectories of the policy packages shown in the main experiment (compare Fig. 11). As shown in Fig. 18, only a very low level of the state grant does not lead to a turnaround in the destruction of machine capacity, which might even lead to a collapse of the production sector in the most extreme scenario as described in the main body of the article (see Fig. 12).

As a result of the lower health and the consecutive lower productivity of mine workers in the South, lower state grants result in higher employment in the mining sector (Fig. 19). As expected, the real GDP does not differ significantly for different levels of the state grant (Fig. 20).

\section{Appendix 4 - Formulas}

\section{Household budget calculation}

$$
m_{h, t}=i n_{h, t}+s_{h, t} \sigma_{1}+\left(\left(1-\frac{s_{h, t}}{s_{h, t}^{\max }}\right) s_{h, t} \sigma_{1}\right)
$$

\section{Consumption good firms}

\section{Price setting and production plan}

Consumption firm depreciation rate: $\delta_{1}^{\text {cons }}$.

Inventory update:

$$
q_{i, t-1}^{p s}=q_{i, t-1}^{p s}\left(1-\delta_{1}^{c o n s}\right)
$$

Production plan:

$$
q_{i, t}^{p^{\prime}}=q_{i, t-1}^{p}+q_{i, t}^{e x}-q_{i, t-1}^{p s}
$$

Optimal reserve level proportional to the previously produced goods $\left(q_{i, t-1}^{p}\right)$ by the factor $a_{2}$ :

$$
q_{i, t}^{o p t}=\frac{q_{i, t-1}^{p} \alpha_{2}}{1+\alpha_{2}}
$$

Sector specific maximum price change, based on the average price of all consumption good firms within one region $(R=\{N ; S\})$ after one year of the simulation: 


$$
p_{R}^{m c h}=\bar{p}_{R, t=12}
$$

\section{Price and excess demand adaptation}

Adaptation process of the price of the good $\left(p_{i, t}\right)$ by a fraction $\left(\alpha_{2}\right)$, depending on the sales in the last period:

- Lower sales than expected $\left(q_{i, t-1}^{p s}>2 q_{i, t}^{\text {opt }}\right)$, price and production are decreased strongly:

$$
\begin{gathered}
p_{i, t}=p_{i, t-1}-\left(1+\alpha_{2}\right) p_{R}^{m c h} \\
q_{i, t}^{e x}=-\alpha_{4} q_{i, t}^{o p t}
\end{gathered}
$$

- Somewhat lower sales than expected $\left(q_{i, t}^{o p t}\left(1+\alpha_{8}\right)<q_{i, t-1}^{p s}<2 q_{i, t}^{o p t}\right)$, price is decreased in relation to the difference between the inventory and the reserve optimal, and production is decreased slightly:

$$
\begin{gathered}
p_{i, t}=p_{i, t-1}-\left(\frac{q_{i, t-1}^{p s}-q_{i, t}^{o p t}}{q_{i, t}^{o p t}}\right) p_{R}^{m c h} \\
q_{i, t}^{e x}=-\frac{\alpha_{4}}{2} q_{i, t}^{o p t}
\end{gathered}
$$

- Sales more or less as expected $\left(q_{i, t}^{o p t} /\left(1+\alpha_{4}\right) \leq q_{i, t-1}^{p s} \leq q_{i, t}^{o p t}\left(1+\alpha_{8}\right)\right)$, price and production are kept the same:

$$
\begin{gathered}
p_{i, t}=p_{i, t-1} \\
q_{i, t}^{e x}=0
\end{gathered}
$$

- Higher sales than expected $\left(0<q_{i, t-1}^{p s}<q_{i, t}^{o p t} /\left(1+\alpha_{8}\right)\right)$, price is increased in relation to the difference between the inventory and the reserve optimal, and production is increased slightly:

$$
p_{i, t}=p_{i, t-1}+\left(\frac{q_{i, t}^{o p t}-q_{i, t-1}^{p s}}{q_{i, t}^{o p t}}\right) p_{R}^{m c h}
$$




$$
q_{i, t}^{e x}=\frac{\alpha_{4}}{2} \mathrm{q}_{i, t}^{o p t}
$$

- Much higher sales than expected - all reserves are sold, price and production is increased strongly:

$$
\begin{gathered}
p_{i, t}=p_{i, t-1}+\left(1+\alpha_{3}\right) p_{R}^{m c h} \\
q_{i, t}^{e x}=\alpha_{4} q_{i, t}^{o p t}
\end{gathered}
$$

Price minimum - per-unit production costs $\left(A C_{i, t}\right)$ :

$$
p_{i, t}=\max \left(A C_{i, t}, p_{i, t}\right)
$$

The actual adoption of the new price $\left(p_{i, t}\right)$ is only implemented with a certain probability $X_{1}>\theta_{1}$ with $X_{1} \sim U(0,1)$. If the condition is not met, the old price is kept $\left(p_{i, t-1}\right)$.

New production plan:

$$
q_{i, t}^{p^{\prime}}=q_{i, t-1}^{p}+q_{i, t}^{e x}-q_{i, t-1}^{p s}
$$

Production function:

$$
q_{i, t}=\alpha_{6}^{c o n s} \min \left(x_{i, t}^{c}, \alpha_{5}^{c o n s} x_{i, t}^{l}\right)
$$

\section{Hiring and firing labor}

Needed labor $\left(x_{i, t}^{l^{\prime}}\right)$, and needed machine capacity $\left(x_{i, t}^{c^{\prime}}\right)$, based on the planned production $\left(q_{i, t}^{p^{\prime}}\right)$ and production inputs (see production function, 9_cons):

$$
\begin{gathered}
x_{i, t}^{l^{\prime}}=\frac{q_{i, t}^{p^{\prime}}}{\alpha_{6}^{\text {cons }} \alpha_{5}^{\text {cons }}} \\
x_{i, t}^{c^{\prime}}=\frac{q_{i, t}^{p^{\prime}}}{\alpha_{6}^{\text {cons }}}
\end{gathered}
$$

If the labor available is not sufficient for the intended production $\left(x_{i, t-1}^{l}<x_{i, t}^{l^{\prime}}\right)$, the firm seeks to hire more workers. If there are unemployed households in the region $\left(U N_{R, t}\right)$, where $\mathrm{R}$ is the region), it hires as many as needed $\left(x_{i, t}^{l-h i r e}\right)$. A firm can, however, only increase the labor force by $\max a_{7}$. 


$$
\begin{gathered}
x_{i, t}^{l-h i r e}=\min \left(\alpha_{7} x_{i, t-1}^{l}, U N_{R, t}, x_{i, t}^{l^{\prime}}-x_{i, t-1}^{l}\right) \\
x_{i, t}^{l}=x_{i, t-1}^{l}+x_{i, t}^{l \_ \text {hire }}
\end{gathered}
$$

If not enough labor is available $\left(U N_{R, t}<x_{i, t}^{l^{\prime}}-x_{i, t-1}^{l}\right)$, or the max increase limit was reached $\left(\alpha_{7} x_{i, t-1}^{l}<x_{i, t}^{l^{\prime}}-x_{i, t-1}^{l}\right)$, the highest possible amount is hired and the planned production is corrected downwards:

$$
q_{i, t}^{p^{\prime}}=\alpha_{5}^{\text {cons }} \min \left(q_{i, t}^{p^{\prime}}, \alpha_{6}^{\text {cons }} x_{i, t}^{l}\right)
$$

If a firm has too much labor available than needed $\left(x_{i, t-1}^{l}>x_{i, t}^{l^{\prime}}\right)$, it fires the surplus. Only $\max \alpha_{7} x_{i, t-1}^{l}$ workers can be fired.

$$
\begin{gathered}
x_{i, t}^{l \text { fire }}=\min \left(\alpha_{7} x_{i, t-1}^{l}, x_{i, t-1}^{l}-x_{i, t}^{l^{\prime}}\right) \\
x_{i, t}^{l}=x_{i, t-1}^{l}-x_{i, t}^{l \text { fire }}
\end{gathered}
$$

\section{Machine capacity adjustment}

Machine capacity $\left(x_{i, t}^{c}\right)$ depreciation and value $\left(\omega_{i, t}^{c}\right)$ amortization, based on the depreciation rate $\left(\alpha_{9}\right)$ :

$$
\begin{gathered}
x_{i, t}^{c}=\alpha_{9} x_{i, t-1}^{c} \\
\omega_{i, t}^{c}=\alpha_{9} \omega_{i, t-1}^{c}
\end{gathered}
$$

Machine capacity purchase if $\left(x_{i, t}^{c}<x_{i, t}^{c^{\prime}}\right)$

Each consumption firm has a shortlist of $\alpha_{10}$ capital firms, from which it can buy machine capacities. This list is updated every three months, following the same rules like the update of the households' shortlist of consumption good firms (see main chapter 3.1).

Needed financial means $\left(c o_{i, t}^{c}\right)$ depend on the mean price all capital firms on the list $\left(\overline{p c}_{t}^{p r e f}\right)$ :

$$
c o_{i, t}^{c}=\overline{p c}_{t}^{p r e f}\left(x_{i, t}^{c^{\prime}}-x_{i, t}^{c}\right)
$$

Purchase if $\left(c o_{i, t}^{c}<l_{i, t}\right)$

Credit application if $\left(c o_{i, t}^{c}>l_{i, t}\right)$, credit granted if 


$$
r_{i, t}^{e}>v_{1} i r
$$

Requests the same share $\left(x^{c} / \alpha_{10}\right)$ from each capital-firm on their list, in total matching the needed machine capacities. Repeated until either $95 \%$ of needed machine capacities are received, or the capital firms on the list are out of inventory.

\section{Capital firms}

\section{Price setting and production plan}

Capital firm depreciation rate: $\delta_{1}^{\text {cap }}$

Inventory update:

$$
q c_{i, t-1}^{p s}=q c_{i, t-1}^{p s}\left(1-\delta_{1}^{c a p}\right)
$$

Production plan:

$$
q c_{i, t}^{p^{\prime}}=q c_{i, t-1}^{p}+q c_{i, t}^{e x}-q c_{i, t-1}^{p s}
$$

Optimal reserve level:

$$
q c_{i, t}^{o p t}=\frac{q c_{i, t-1}^{p} \alpha_{2}}{1+\alpha_{2}}
$$

Sector specific maximum price change:

$$
p c^{m c h}=\overline{p c}_{t=12}
$$

\section{Price and excess demand adaptation}

- Lower sales than expected $\left(q c_{i, t-1}^{p s}>2 q c_{i, t}^{o p t}\right)$

$$
\begin{gathered}
p c_{i, t}=p c_{i, t-1}-\left(1+\alpha_{3}\right) p c^{m c h} \\
q c_{i, t}^{e x}=-\alpha_{4} q c_{i, t}^{o p t}
\end{gathered}
$$

- Somewhat lower sales than expected $\left(q c_{i, t}^{o p t}\left(1+\alpha_{8}\right)<q c_{i, t-1}^{p s} \leq 2 q c_{i, t}^{o p t}\right)$

$$
p c_{i, t}=p c_{i, t-1}-\left(\frac{q c_{i, t-1}^{p s}-q c_{i, t}^{o p t}}{q c_{i, t}^{o p t}}\right) p c^{m c h}
$$




$$
q c_{i, t}^{e x}=\frac{-\alpha_{4}}{2} * q c_{i, t}^{o p t}
$$

- Sales more or less as expected $\left(q c_{i, t}^{o p t} /\left(1+\alpha_{4}\right) \leq q c_{i, t-1}^{p s} \leq q c_{i, t}^{o p t}\left(1+\alpha_{8}\right)\right)$

$$
\begin{gathered}
p c_{i, t}=p c_{i, t-1} \\
q c_{i, t}^{e x}=0
\end{gathered}
$$

- Higher sales than expected $\left(0<q c_{i, t-1}^{p s}<q c_{i, t}^{o p t} /\left(1+\alpha_{8}\right)\right)$

$$
\begin{gathered}
p c_{i, t}=p c_{i, t-1}+\left(\frac{q c_{i, t}^{o p t}-q c_{i, t-1}^{p s}}{q c_{i, t}^{o p t}}\right) p c^{m c h} \\
q c_{i, t}^{e x}=\frac{\alpha_{4}}{2} q c_{i, t}^{o p t}
\end{gathered}
$$

- Much higher sales than expected - all reserves are sold $\left(q c_{i, t-1}^{p s}=0\right)$

$$
\begin{gathered}
p c_{i, t}=p c_{i, t-1}+\left(1+\alpha_{3}\right) p c^{m c h} \\
q c_{i, t}^{e x}=\alpha_{4} q c_{i, t}^{o p t}
\end{gathered}
$$

Price minimum - per-unit production costs $\left(A C c_{i, t}\right)$ :

$$
p c_{i, t}=\max \left(A C c_{i, t}, p c_{i, t}\right)
$$

The actual adoption of the new price $\left(p c_{i, t}\right)$ is only implemented with the probability $X_{1}>\theta_{1}$ with $X_{1} \sim U(0,1)$. If the condition is not met, the old price is kept $\left(p c_{i, t-1}\right)$.

New production plan:

$$
q c_{i, t}^{p^{\prime}}=q c_{i, t-1}^{p}+q c_{i, t}^{e x}-q c_{i, t-1}^{p s}
$$

Capital intensity coefficient: $\alpha_{5}^{c a p}$

Production function:

$$
q c_{i, t}^{p}=\alpha_{6}^{c a p} \min \left(x_{i, t}^{c}, \alpha_{5}^{c a p} x_{i, t}^{l}, \alpha_{12} x_{i, t}^{r}\right)
$$

\section{Hiring and firing labor}

Needed labor $\left(x_{i, t}^{l \prime}\right)$ : 


$$
x_{i, t}^{l^{\prime}}=\frac{q c_{i, t}^{p^{\prime}}}{\alpha_{6}^{c a p} \alpha_{5}^{c a p}}
$$

Required machine capacity $\left(x_{i, t}^{c^{\prime}}\right)$ :

$$
x_{i, t}^{c^{\prime}}=\frac{q c_{i, t}^{p^{\prime}}}{\alpha_{6}^{c a p}}
$$

Hiring, if $\left(x_{i, t-1}^{l}<x_{i, t}^{l^{\prime}}\right)$ :

$$
\begin{gathered}
x_{i, t}^{l \_ \text {hire }}=\min \left(\alpha_{7} x_{i, t-1}^{l}, U N_{R=N, t}, x_{i, t}^{l^{\prime}}-x_{i, t-1}^{l}\right) \\
x_{i, t}^{l}=x_{i, t-1}^{l}+x_{i, t}^{l \text { hire }}
\end{gathered}
$$

Correction of planned production if $\left(U N_{R=N, t}<x_{i, t}^{l^{\prime}}-x_{i, t-1}^{l}\right)$, or $\left(\alpha_{7} x_{i, t-1}^{l}<x_{i, t}^{l^{\prime}}-x_{i, t-1}^{l}\right)$

$$
q c_{i, t}^{p^{\prime}}=\alpha_{5}^{c a p} \min \left(q c_{i, t}^{p^{\prime}}, \alpha_{6}^{c a p} x_{i, t}^{l}\right)
$$

Firing, if $\left(x_{i, t-1}^{l}>x_{i, t}^{l^{\prime}}\right)$ :

$$
\begin{gathered}
x_{i, t}^{l-f i r e}=\min \left(\alpha_{7} x_{i, t-1}^{l}, x_{i, t-1}^{l}-x_{i, t}^{l^{\prime}}\right) \\
x_{i, t}^{l}=x_{i, t-1}^{l}-x_{i, t}^{l \text { fire }}
\end{gathered}
$$

\section{Machine capacity purchase}

Machine capacity depreciation and value amortization:

$$
\begin{gathered}
x_{i, t}^{c}=\alpha_{9} x_{i, t-1}^{c} \\
\omega_{i, t}^{c}=\alpha_{9} \omega_{i, t-1}^{c}
\end{gathered}
$$

Machine capacity purchase if $\left(x_{i, t}^{c}<x_{i, t}^{c^{\prime}}\right)$

Shortlist of $\alpha_{10}$ other capital firms, updated every three months, following the same rules like the update of the households' shortlist of consumption good firms (see main chapter 3.1).

Needed financial means $\left(\operatorname{coc}_{i, t}^{c}\right)$ depend on the mean price all capital firms on the list $\left(\overline{p c}_{t}^{p r e f}\right)$ : 


$$
\operatorname{coc}_{i, t}^{c}=\overline{p c}_{t}^{p r e f}\left(x_{i, t}^{c^{\prime}}-x_{i, t}^{c}\right)
$$

Purchase if $\left(\operatorname{coc}_{i, t}^{c}<l_{i, t}\right)$

Credit application if $\left(\operatorname{coc}_{i, t}^{c}>l_{i, t}\right)$, credit granted if

$$
r_{i, t}^{e}>v_{1} i r
$$

Requests the same share $\left(x^{c} / \alpha_{10}\right)$ from each capital-firm on their list, in total matching the needed machine capacities. Repeated until either $95 \%$ of needed machine capacities are received, or the capital firms on the list are out of inventory.

\section{Resource purchase}

Resource purchase is analogous to the machine capacity purchase. The amount needed $\left(x_{i, t}^{r^{\prime}}\right)$ has to be determined, taking into consideration potentially unused and stored resources from the last period $\left(x_{i, t-1}^{r}\right)$ :

$$
x_{i, t}^{r^{\prime}}=\frac{q c_{i, t}^{p^{\prime}}}{\alpha_{6}^{c a p} \alpha_{12}}-\left(x_{i, t-1}^{r}\right)
$$

If the capital firm needs resources $\left(x_{i, t}^{r^{\prime}}>0\right)$, it follows the same logic of machinecapacity purchase. They have a shortlist of $\alpha_{11}$ mines, updated every three months, following the same rules like the update of the households' shortlist of consumption good firms (see main chapter 3.1) and apply for credits if not enough financial means are available (see equations 19_cap and 20_cap above). They also purchase from all mines on their shopping-list in equal shares and repeat the purchasing process, until either $95 \%$ of needed resources are received, or the mines on the list are out of inventory.

\section{Mines}

\section{Price setting and production plan}

Mine depreciation rate: $\delta_{1}^{\text {mine }}$

Inventory update:

$$
q m_{i, t-1}^{p s}=q m_{i, t-1}^{p s}\left(1-\delta_{1}^{\text {mine }}\right)
$$

Production plan:

$$
q m_{i, t}^{p^{\prime}}=q m_{i, t-1}^{p}+q m_{i, t}^{e x}-q m_{i, t-1}^{p s}
$$


Optimal reserve level:

$$
q m_{i, t}^{o p t}=\frac{q m_{i, t-1}^{p} \alpha_{2}}{1+\alpha_{2}}
$$

Sector specific maximum price change:

$$
p m^{m c h}=\overline{p m}_{t=12}
$$

Price and excess demand adaptation:

- Lower sales than expected $\left(q m_{i, t-1}^{p s}>2 q m_{i, t}^{o p t}\right)$

$$
\begin{gathered}
p m_{i, t}=p m_{i, t-1}-\left(1+\alpha_{3}\right) p m^{m c h} \\
q m_{i, t}^{e x}=-\alpha_{4} q m_{i, t}^{o p t}
\end{gathered}
$$

- Somewhat lower sales than expected $\left(q m_{i, t}^{o p t}\left(1+\alpha_{8}\right)<q m_{i, t-1}^{p s} \leq 2 q m_{i, t}^{o p t}\right)$

$$
\begin{gathered}
p m_{i, t}=p m_{i, t-1}-\left(\frac{q m_{i, t-1}^{p s}-q m_{i, t}^{o p t}}{q m_{i, t}^{o p t}}\right) p m^{m c h} \\
q m_{i, t}^{e x}=\frac{-\alpha_{4}}{2} q m_{i, t}^{o p t}
\end{gathered}
$$

- Sales more or less as expected $\left(q m_{i, t}^{o p t} /\left(1+\alpha_{4}\right) \leq q m_{i, t-1}^{p s} \leq q m_{i, t}^{o p t}\left(1+\alpha_{8}\right)\right)$

$$
\begin{gathered}
p m_{i, t}=p m_{i, t^{\wedge}-1} \\
q m_{i, t}^{e x}=0
\end{gathered}
$$

- Higher sales than expected $\left(0<q m_{i, t-1}^{p s}<q m_{i, t}^{o p t} /\left(1+\alpha_{8}\right)\right)$

$$
\begin{gathered}
p m_{i, t}=p m_{i, t-1}+\left(\frac{q m_{i, t}^{o p t}-q m_{i, t-1}^{p s}}{q m_{i, t}^{o p t}}\right) p m^{m c h} \\
q m_{i, t}^{e x}=\frac{\alpha_{4}}{2} q m_{i, t}^{o p t}
\end{gathered}
$$

- Much higher sales than expected - all reserves are sold $\left(q m_{i, t-1}^{p s}=0\right)$ 


$$
\begin{gathered}
p m_{i, t}=p m_{i, t-1}+\left(1+\alpha_{3}\right) p m^{m c h} \\
q m_{i, t}^{e x}=\alpha_{4} q m_{i, t}^{o p t}
\end{gathered}
$$

Price minimum - per-unit production costs $\left(A C m_{i, t}\right)$ :

$$
p m_{i, t}=\max \left(A C m_{i, t}, p m_{i, t}\right)
$$

The actual adoption of the new price $p m_{i, t}$ is only implemented with the probability $X_{1}>\theta_{1}$ with $X_{1} \sim U(0,1)$. If the condition is not met, the old price $\left(\mathrm{pm}_{i, t-1}\right)$ is kept.

New production plan:

$$
q m_{i, t}^{p^{\prime}}=q m_{i, t-1}^{p}+q m_{i, t}^{e x}-q m_{i, t-1}^{p s}
$$

Capital intensity coefficient: $\alpha_{5}^{\text {mine }}$

Production function:

$$
q m_{i, t}^{p}=\alpha_{6}^{\text {mine }} \min \left(x_{i, t}^{c}, \alpha_{5}^{\text {mine }} x_{i, t}^{l-p r o d}\right)
$$

Hiring and firing labor

Needed labor $\left(x_{i, t}^{l-\text { prod }^{\prime}}\right)$ :

$$
x_{i, t-1}^{l \_ \text {prod }^{\prime}}=\frac{q m_{i, t}^{p^{\prime}}}{\alpha_{6}^{\text {mine }} \alpha_{5}^{\text {mine }}}
$$

Needed machine capacity $\left(x_{i, t}^{c \prime}\right)$ :

$$
x_{i, t}^{c^{\prime}}=\frac{q m_{i, t}^{p^{\prime}}}{\alpha_{6}^{\min e}}
$$

Hiring, if $\left(x_{i, t-1}^{l \_ \text {prod }}<x_{i, t}^{l \_p r o d^{\prime}}\right)$ :

$$
\begin{gathered}
x_{i, t}^{l-h i r e}=\min \left(\alpha_{7} x_{i, t-1}^{l}, U N_{R=S, t}, x_{i, t}^{l-\text { prod }^{\prime}}-x_{i, t-1}^{l \_ \text {prod }}\right) \\
x_{i, t}^{l \_ \text {prod }}=x_{i, t-1}^{l \_ \text {prod }}+x_{i, t}^{l \_ \text {hire }}
\end{gathered}
$$

Correction of planned production if $\left(U N_{R=S, t}<x_{i, t}^{l^{\prime}}-x_{i, t-1}^{l}\right)$, or $\left(\alpha_{7} x_{i, t-1}^{l}<x_{i, t}^{l^{\prime}}-x_{i, t-1}^{l}\right)$

$$
q m_{i, t}^{p^{\prime}}=\alpha_{6}^{\text {mine }} \min \left(x_{i, t-1}^{c}, \alpha_{5}^{\text {mine }} x_{i, t}^{l \_p r o d}\right)
$$

Firing, if $\left(x_{i, t-1}^{l}>x_{i, t}^{l^{\prime}}\right)$ : 


$$
\begin{gathered}
x_{i, t}^{l_{-} \text {fire }}=\min \left(\alpha_{7} x_{i, t-1}^{l}, x_{i, t-1}^{l \_ \text {prod }}-x_{i, t}^{L_{\text {pprod }}}\right) \\
x_{i, t}^{l}=x_{i, t-1}^{l}-x_{i, t}^{l_{-} \text {fire }}
\end{gathered}
$$

\section{Machine capacity purchase}

Machine capacity depreciation and value amortization:

$$
\begin{aligned}
x_{i, t}^{c} & =\alpha_{9} x_{i, t-1}^{c} \\
\omega_{i, t}^{c} & =\alpha_{9} \omega_{i, t-1}^{c}
\end{aligned}
$$

Machine capacity purchase if $\left(x_{i, t}^{c}<x_{i, t}^{c^{\prime}}\right)$, from capital firms

Shortlist of $\alpha_{10}$ capital firms, updated every three months, following the same rules like the update of the households' shortlist of consumption good firms and capital firms (see main chapter 3.1).

Needed financial means $\left(\operatorname{com}_{i, t}^{c}\right)$ depend on the mean price of all capital firms on the list of preferred capital good firms $\left(\overline{p c}_{t}^{\text {pref }}\right)$ :

$$
\operatorname{com}_{i, t}^{c}=\overline{p c}_{t}^{\text {pref }}\left(x_{i, t}^{c^{\prime}}-x_{i, t}^{c}\right)
$$

Purchase if $\left(\operatorname{com}_{i, t}^{c}<l_{i, t}\right)$

Credit application if $\left(\operatorname{com}_{i, t}^{c}>l_{i, t}\right)$, credit granted if

$$
r_{i, t}^{e}>v_{1} i r
$$

Requests the same share $\left(x^{c} / \alpha_{10}\right)$ from each capital-firm on their list, in total matching the needed machine capacities. Repeated until either $95 \%$ of needed machine capacities are received, or the capital firms on the list are out of inventory.

\section{Wage payment}

Wages for each mine worker $\left(i n_{h, t}\right)$, dependent on base wage of the mine $\left(w_{i, t}\right)$ and individual agent productivity $\left(p r_{h, t}\right)$

$$
\operatorname{in}_{h, t}=w_{i, t} \operatorname{prod}_{h, t}
$$

\section{Upgrade purchase}

Cost calculation 


$$
\begin{gathered}
c u_{t}^{\text {base }}=\overline{p c}_{t} \alpha_{18}^{\text {mine }} \\
c u_{i, t}^{\text {eval }}=c u_{t}^{\text {base }} x_{i, t}^{c} i_{i, t}^{e}
\end{gathered}
$$

Gamma upgrade

$$
\gamma_{i, t}=\gamma_{i, t-1}-\gamma_{i, t-1} i_{i, t}^{e} \alpha_{19}
$$

\section{Wage adjustment}

All firms change their wages $\left(w_{i, t}\right)$ based on the wage adjustment $\left(w a_{i, t}\right)$, which depends on the change in the price of the own good compared to the last year, with a maximum of the sector specific price adjustment parameter $\alpha_{23}^{\text {sector }}$.

$$
\begin{gathered}
w a_{i, t}=\min \left(\alpha_{23}^{\text {sector }},\left(\max \left(\frac{p m_{i, t}}{p m_{i, t-12}}\right), 1\right)\right) \\
w_{i, t}=w_{i, t-1} w a_{i, t}
\end{gathered}
$$

Funding Open access funding provided by Vienna University of Economics and Business (WU). This study was partly funded by VolkswagenStiftung (grant number 94899).

Data availability The datasets generated and analysed during the study are available from the corresponding author upon request.

\section{Declarations}

Conflict of interest The authors declare that they have no conflict of interest.

Open Access This article is licensed under a Creative Commons Attribution 4.0 International License, which permits use, sharing, adaptation, distribution and reproduction in any medium or format, as long as you give appropriate credit to the original author(s) and the source, provide a link to the Creative Commons licence, and indicate if changes were made. The images or other third party material in this article are included in the article's Creative Commons licence, unless indicated otherwise in a credit line to the material. If material is not included in the article's Creative Commons licence and your intended use is not permitted by statutory regulation or exceeds the permitted use, you will need to obtain permission directly from the copyright holder. To view a copy of this licence, visit http://creativecommons.org/licen ses/by/4.0/.

\section{References}

Acosta A (2013) Extractivism and neoextractivism: two sides of the same curse. In: Lang M, Mokrani D (eds) Beyond development: alternative visions from Latin America. Transnational Inst, pp 61-86 
Amable B (2000) International specialisation and growth. Struct Chang Econ Dyn 11(4):413-431. https:// doi.org/10.1016/S0954-349X(00)00026-6

Amin S (1974) Accumulation on a world scale: Critique of the theory of underdevelopment. New York: Monthly Review Press.

Caiani A, Godin A, Caverzasi E, Gallegati M, Kinsella S, Stiglitz JE (2016) Agent based-stock flow consistent macroeconomics: towards a benchmark model. J Econ Dyn Control 69:375-408

Caiani A, Catullo E, Gallegati M (2018) The effects of fiscal targets in a monetary union: a multi-country agent-based stock flow consistent model. Ind Corp Chang 27(6):1123-1154

Caiani A, Catullo E, Gallegati M (2019) The effects of alternative wage regimes in a monetary union: a multi-country agent based-stock flow consistent model. J Econ Behav Organ 162:389-416

Chen S-H, Chang C-L, Wen M-C (2014) Social networks and macroeconomic stability. Economics: The Open-Access, Open-Assessment E-Journal 8(1):1-40

Chiarella C, Di Guilmi C (2011) The financial instability hypothesis: a stochastic microfoundation framework. J Econ Dyn Control 35(8):1151-1171

Ciarli T, Lorentz A, Savona M, Valente M (2010) The effect of consumption and production structure on growth and distribution. A micro to macro model. Metroeconomica 61(1):180-218

Cincotti S, Raberto M, Teglio A (2010) Credit money and macroeconomic instability in the agent-based model and simulator Eurace. Economics: The Open-Access, Open-Assessment E-Journal 4(1)

Daly HE (1995) Against free trade: neoclassical and steady-state perspectives. J Evol Econ 5(3):313-326. https://doi.org/10.1007/BF01198310

Dawid H, Harting P (2012) Capturing firm behavior in agent-based models of industry evolution and macroeconomic dynamics. Applied Evolutionary Economics, Behavior and Organizations, ed. by G. Bünsdorf, Edward-Elgar:103-130

Dawid H, Harting P, Neugart M (2014) Economic convergence: policy implications from a heterogeneous agent model. J Econ Dyn Control 44:54-80. https://doi.org/10.1016/j.jedc.2014.04.004

Dawid H, Harting P, Neugart M (2018) Cohesion policy and inequality dynamics: insights from a heterogeneous agents macroeconomic model. J Econ Behav Organ 150:220-255. https://doi.org/10.1016/j. jebo.2018.03.015

Delli Gatti D, Desiderio S, Gaffeo E, Cirillo P, Gallegati M (2011) Macroeconomics from the bottom-up. Springer Science \& Business Media

Dinar A, Mendelsohn R, Williams L (2006) The distributional impact of climate change on rich and poor countries. Environ Dev Econ 11(2):159-178. https://doi.org/10.1017/S1355770X05002755

Dorninger C, Hornborg A, Abson DJ, von Wehrden H, Schaffartzik A, Giljum S, Engler J-O, Feller RL, Hubacek K, Wieland H (2021) Global patterns of ecologically unequal exchange: implications for sustainability in the 21st century. Ecol Econ 179:106824. https://doi.org/10.1016/j.ecolecon.2020. 106824

Dosi G, Fagiolo G, Roventini A (2010) Schumpeter meeting Keynes: a policy-friendly model of endogenous growth and business cycles. J Econ Dyn Control 34(9):1748-1767

Dosi G, Roventini A, Russo E (2019) Endogenous growth and global divergence in a multi-country agent-based model. J Econ Dyn Control 101:101-129

Dosi G, Roventini A, \& Russo E (2020) Public policies and the art of catching up: matching the historical evidence with a multicountry agent-based model, industrial and corporate change, 1-26. https://doi. org/10.1093/icc/dtaa057

Dudka S, Adriano DC (1997) Environmental impacts of metal ore mining and processing: a review. J Environ Qual 26(3):590. https://doi.org/10.2134/jeq1997.00472425002600030003x

Eckstein D, Künzel V, Schäfer L, Winges M (2019) Global climate risk index 2020. Germanwatch, Bonn

Emmanuel A (1972) Unequal exchange: A study of the imperialism of trade. New York: Monthly Review Press.

European Parliament (2021) European Parliament resolution of 10 March 2021 with recommendations to the Commission on corporate due diligence and corporate accountability. https://www.europarl. europa.eu/doceo/document/TA-9-2021-0073_EN.pdf. Accessed 17 March 2021

Fagiolo G, Reyes J, Schiavo S (2010) The evolution of the world trade web: a weighted-network analysis. J Evol Econ 20(4):479-514. https://doi.org/10.1007/s00191-009-0160-x

Faracik B (2017) Implementation of the UN guiding principles on business and human rights: study. [European Parliament], Brussels

Fischer K, Reiner C, Staritz C (eds) (2021) Globale Warenketten und ungleiche Entwicklung: Arbeit, Kapital, Konsum, Natur, 1st edn. Wien, Mandelbaum 
Foster JB, Holleman H (2014) The theory of unequal ecological exchange: a Marx-Odum dialectic. J Peasant Stud 41(2):199-233. https://doi.org/10.1080/03066150.2014.889687

Gaffard J-L, Saraceno F (2012) International trade and domestic distortions. J Evol Econ 22(2):275-301

García-Herrero A, Chiacchio F (2017) The European Union with the Community of Latin America and the Caribbean: where do we stand? Bruegel

Giarracca N, Teubal M (2014) Argentina: Extractivist dynamics of soy production and open-pit mining. In: Veltmeyer H, Petras JF (eds) The new extractivism: a post-neoliberal development model or imperialism of the twenty-first century? Zed Books, London, New York, pp 47-79

Godley W, Lavoie M (2006) Monetary economics: an integrated approach to credit, money, income, production and wealth. Springer

Grauwe P de, Gerba E (2017) Rationalising the irrational: how relevant are beliefs for supply side frictions and business cycle fluctuations

Gudynas E (2009) Diez tesis urgentes sobre el nuevo extractivismo. Contextos y demandas bajo el progresismo sudamericano actual. In: Centro Andino de Acción Popular, Centro Latinoamericano de Ecología Social (eds) Extractivismo, política y sociedad, Extractivismo. Política y Sociedad, Quito, pp 187-225

Hanappi H (2019) From integrated capitalism to disintegrating capitalism. Scenarios of a third world war. SCIREA, J Sociol 3(3):102-128

Hanappi H, Scholz-Wäckerle M (2017) Evolutionary political economy: content and methods. Forum Social Econ 2(1):1-18. https://doi.org/10.1080/07360932.2017.1287748

Harvey D (2006) Spaces of global capitalism. Verso

Herrmann-Pillath C (2006) The true story of wine and cloth, or: building blocks of an evolutionary political economy of international trade. J Evol Econ 16(4):383-417. https://doi.org/10.1007/ s00191-006-0022-8

Hornborg A (2006) Ecosystems and world-systems: accumulation as an ecological process. In: ChaseDunn C, Babones SJ (eds) (2006) Global social change. Historical and comparative perspectives. The Johns Hopkins University Press, Baltimore, pp 161-175

Hornborg A, McNeill JR, Martínez-Alier J (eds) (2007) Rethinking environmental history: world-system history and global environmental change. Altamira Press

Jorgenson AK (2006) Unequal ecological exchange and environmental degradation: a theoretical proposition and Cross-National Study of deforestation, 1990-2000*. Rural Sociol 71(4):685-712. https:// doi.org/10.1526/003601106781262016

Jorgenson AK, Rice J (2007) Uneven ecological exchange and consumption-based environmental impacts: a cross-national investigation. Rethinking environmental history: world-system history and global environmental change:273-288

Kapeller J, Scholz-Wäckerle M (2016) Evolutionary political economy and the complexity of economic policy: power, knowledge and learning. In: Gräbner C, Heinrich T, Schwardt H (eds) Policy implications of recent advances in evolutionary and institutional economics. Routledge, Abingdon and New York, pp 43-61

Kapeller J, Schütz B, Tamesberger D (2016) From free to civilized trade: a European perspective. Rev Soc Econ 74(3):320-328. https://doi.org/10.1080/00346764.2016.1168033

Kapp KW (1950) Social costs of Private Enterprise. Shocken, New York

Kapp KW (1970) Environmental disruption and social costs: a challenge to economics. Kyklos 23(4):833-848

Kingston W (2000) A spectre is haunting the world-the spectre of global capitalism. In: Capitalism and democracy in the $21^{\text {st }}$ century, vol vol 10 . Springer, pp 83-108

Krausmann F, Schandl H, Eisenmenger N, Giljum S, Jackson T (2017) Material flow accounting: measuring global material use for sustainable development. Annu Rev Environ Resour 42:647-675

Lamperti F, Dosi G, Napoletano M, Roventini A, Sapio A (2018) Faraway, so close: coupled climate and economic dynamics in an agent-based integrated assessment model. Ecol Econ 150:315-339

Landesmann MA, Stöllinger R (2019) Structural change, trade and global production networks: an 'appropriate industrial policy'for peripheral and catching-up economies. Struct Chang Econ Dyn 48:7-23

Lang M, Mokrani D (eds) (2013) Beyond development: alternative visions from Latin America. Transnational Inst

Lawrence KS (2009) The thermodynamics of unequal exchange: energy use, CO2 emissions, and GDP in the world-system, 1975-2005. Int J Comp Sociol 50(3-4):335-359 
Lee S-H, Park H-S, Cho S-B (2010) Empirical analysis of international trade market using evolutionary multi-agent modeling with game theory. IEEE Congress on Evolutionary Computation:1-7. https://doi.org/10.1109/CEC.2010.5586525

Lengnick M (2013) Agent-based macroeconomics: a baseline model. J Econ Behav Organ 86:102120. https://doi.org/10.1016/j.jebo.2012.12.021

Lessenich S (2019) Living well at Others' expense: the hidden costs of Western prosperity. John Wiley \& Sons

Lorentz A, Ciarli T, Savona M, Valente M (2016) The effect of demand-driven structural transformations on growth and technological change. J Evol Econ 26(1):219-246

Maechler S, Graz J-C (2020) Is the sky or the earth the limit? Risk, uncertainty and nature. Review of International Political Economy: 1-22. https://doi.org/10.1080/09692290.2020.1831573

Maggi G (1993) Technology gap and international trade: an evolutionary model. J Evol Econ 3(2):109-126. https://doi.org/10.1007/BF01213829

Mainwaring L (1993) Endogenous NIC-formation in a north-south framework. J Evol Econ 3(4):317335. https://doi.org/10.1007/BF01194945

Moran DD, Lenzen M, Kanemoto K, Geschke A (2013) Does ecologically unequal exchange occur? Ecol Econ 89:177-186. https://doi.org/10.1016/j.ecolecon.2013.02.013

Muradian R, Martinez-Alier J (2001) Trade and the environment: from a 'Southern' perspective. Ecol Econ 36(2):281-297. https://doi.org/10.1016/S0921-8009(00)00229-9

OECD (2020) Average annual wages. https://stats.oecd.org/Index.aspx?DataSetCode=AV_AN_ WAGE.

Petrovic M, Ozel B, Teglio A, Raberto M, Cincotti S (2017) Eurace open: an agent-based multi-country model. Universidad Jaume, Economics Department

Petrović M, Ozel B, Teglio A, Raberto M, Cincotti S (2020) Should I stay or should I go? An agentbased setup for a trading and monetary union. J Econ Dyn Control 113:103866

Rengs B, Scholz-Wäckerle M (2017) Fiscal policy and redistribution in an evolutionary macroeconomic model of an artificial monetary union. In: Hanappi H, Katsikides S, Scholz-Wäckerle M (eds) Theory and method of evolutionary political economy: a Cyprus symposium. Routledge, Abingdon, Oxon, New York, pp 193-213

Rengs B, Scholz-Wäckerle M (2019) Consumption \& class in evolutionary macroeconomics. J Evol Econ 29(1):229-263

Rengs B, Wäckerle M (2014) A computational agent-based simulation of an artificial monetary union for dynamic comparative institutional analysis. Proceedings of the 2014 IEEE Conference on Computational Intelligence for Financial Engineering \& Economics (CIFEr):427-434

Rengs B, Scholz-Wäckerle M, van den Bergh J (2020) Evolutionary macroeconomic assessment of employment and innovation impacts of climate policy packages. J Econ Behav Organ $169: 332-368$

Ricci A (2019) Unequal exchange in the age of globalization. Rev Rad Polit Econ 51(2):225-245. https:// doi.org/10.1177/0486613418773753

Ricetti L, Russo A, Gallegati M (2013) Unemployment benefits and financial leverage in an agent based macroeconomic model. Economics: The Open-Access, Open-Assessment E-Journal 7(1):1-44

Safarzyńska K, van den Bergh JC (2016) Integrated crisis-energy policy: macro-evolutionary modelling of technology, finance and energy interactions. Technol Forecast Soc Chang 114:119-137

Schaffartzik A, Mayer A, Eisenmenger N, Krausmann F (2016) Global patterns of metal extractivism, 1950-2010: providing the bones for the industrial society's skeleton. Ecol Econ 122:101-110

Seppecher P (2012) Flexibility of wages and macroeconomic instability in an agent-based computational model with endogenous money. Macroecon Dyn 16(S2):284-297

Shleifer A (2004) Does competition destroy ethical behavior? Am Econ Rev 94(2):414-418

Smit L, Bright C, McCorquodale R, Bauer M, Deringer H, Baeza-Breinbauer D, Torres-Cortés F, Alleweldt F, Kara S, Salinier C, Tobed HT (2020) Study on due diligence requirements through the supply chain: final report. Publications Office of the European Union, Luxembourg

Suwandi I (2019) Value chains: the new economic imperialism. Monthly Review Press

Svampa M (2013) Resource extractivism and alternatives: Latin American perspectives on development. In: Lang M, Mokrani D (eds) Beyond development: alternative visions from Latin America. Transnational Inst, pp 117-143

Veltmeyer H, Petras JF (eds) (2014) The new extractivism: a post-neoliberal development model or imperialism of the twenty-first century? Zed books. New York, London

Wallerstein I (1983) Historical capitalism with capitalist civilization. London and New York, Verso 
Wilensky U (1999) NetLogo. http://ccl.northwestern.edu/netlogo/. Center for Connected Learning and Computer-Based Modeling. Northwestern University, Evanston, IL

Wolf S, Fürst S, Mandel A, Lass W, Lincke D, Pablo-Martí F, Jaeger C (2013) A multi-agent model of several economic regions. Environ Model Softw 44:25-43. https://doi.org/10.1016/j.envsoft.2012. 12.012

Publisher's note Springer Nature remains neutral with regard to jurisdictional claims in published maps and institutional affiliations. 